\title{
Influence of Heat Treatment on the Corrosion Behaviour of Aluminium Silver Nano Particle/Calcium Carbonate Composite
}

\author{
Omolayo Michael Ikumapayi $1, * \mathbb{C}$, Esther T. Akinlabi ${ }^{2,3} \mathbb{D}^{\circ}$, Olayinka Oluwatosin Abegunde ${ }^{4}$, \\ Precious Ken-Ezihuo ${ }^{1}$, Henry A. Benjamin ${ }^{1}{ }^{(1)}$, Sunday Adeniran Afolalu ${ }^{5}$ and Stephen A. Akinlabi ${ }^{6}$ \\ 1 Department of Mechanical and Mechatronics Engineering, Afe Babalola University, Ado Ekiti 360101, Nigeria; \\ chimzarumken@gmail.com (P.K.-E.); benjaminha@abuad.edu.ng (H.A.B.) \\ 2 Directorate, Pan African University for Life and Earth Sciences, Ibadan 200284, Nigeria; etakinlabi@gmail.com \\ 3 Department of Mechanical Engineering Science, University of Johannesburg, Auckland Park, \\ Johannesburg 2006, South Africa \\ 4 Materials Science, Energy and Nanoengineering, Mohammed VI Polytechnic University, \\ Ben Guerir 43150, Morocco; ABEGUNDE.Oluwatosin@um6p.ma \\ 5 Department of Mechanical Engineering, Covenant University, Ota 112104, Nigeria; \\ sunday.afolalu@covenantuniversity.edu.ng \\ 6 Department of Mechanical Engineering, Butterworth Campus, Walter Sisulu University, \\ Mthatha 4960, South Africa; stephenakinlabi@gmail.com \\ * Correspondence: ikumapayi.omolayo@abuad.edu.ng
}

\section{check for} updates

Citation: Ikumapayi, O.M.; Akinlabi, E.T.; Abegunde, O.O.; Ken-Ezihuo, P.; Benjamin, H.A.; Afolalu, S.A.; Akinlabi, S.A. Influence of Heat Treatment on the Corrosion Behaviour of Aluminium Silver Nano Particle/Calcium Carbonate Composite. J. Compos. Sci. 2021, 5, 280. https://doi.org/10.3390/jcs5100280

Academic Editor: Swadesh Kumar Singh

Received: 7 August 2021

Accepted: 9 September 2021

Published: 16 October 2021

Publisher's Note: MDPI stays neutral with regard to jurisdictional claims in published maps and institutional affiliations.

Copyright: (c) 2021 by the authors. Licensee MDPI, Basel, Switzerland. This article is an open access article distributed under the terms and conditions of the Creative Commons Attribution (CC BY) license (https:// creativecommons.org/licenses/by/ $4.0 /)$.

\begin{abstract}
Corrosion is one of the leading sources of material failure and deterioration in society. Scholars have proposed different techniques to mitigate corrosion. This research study explores and validates one of these techniques. An Aluminium metal matrix (AMC) was produced using the stir casting method with various weight percentages of $\mathrm{AgNp}$ and $\mathrm{CaCO}_{3}$ reinforcements. Heat treatment was performed on the samples to enhance the metallurgical and corrosion properties of the materials. The corrosion rate of the AMC samples was tested in different corrosive media (neutral and acidic) with different concentrations using the weight loss analysis technique for several days. It was observed that the corrosion rate of the AMC relies on the nature of the electrolyte and the percentage concentration of this electrolyte. The heat treatment improves the corrosion resistance of the AMC samples. In addition, an increase in the \% weight composition of the reinforcement $\left(\mathrm{AgNp}+\mathrm{CaCO}_{3}\right)$ results in a reduction in the corrosion rate of the $\mathrm{AMC}$ in both corrosive media. The optimal \%weight composition was found to be $4 \%$ for the hybrid reinforcement of $\mathrm{AgNp}+\mathrm{CaCO}_{3}$ and $6 \%$ for the $\mathrm{CaCO}_{3}$ reinforcement in both the untreated and heat-treated samples.
\end{abstract}

Keywords: aluminium; composite; corrosion; reinforcement; stir casting

\section{Introduction}

The properties of materials play a crucial role in selection and usage in engineering applications. One of the widely used materials in the engineering field is Aluminium (Al). Aluminium has found widespread applications in different industries due to its availability and favourable properties. Aluminium alloys have high corrosion resistance, high thermal conductivity, adequate strength characteristics, recyclability, ductility, strength and especially irregularity. Therefore, it has been generally utilised in numerous territories of industry such as aviation, structural development, marine ventures and especially in-car applications [1-3]. The need for the development of new advanced materials with superior mechanical and metallurgical properties that can serve effectively in the aggressive environment is on the rise. Several creative industries have started to search for alternative engineering materials with superior properties. Adding reinforcement particles to monolithic metal to produce metal matrix composites (MMC) has proven to be a successful solution for tuning and improving the properties of Aluminium and its alloys. According to researchers, a "metal matrix composite" is when two or more different materials (metal 
matrix and reinforcements) are combined to create a superior and unique material [4-9]. Metal matrix composite materials are designed to combine the desirable attributes of metals and reinforcement. Reinforcements are employed to enhance the properties of the metals such as density, hardness, strength, wear-resistance, and stiffness. Reinforced Aluminium materials possess several distinguished advantages over monolithic Aluminium such as increased Young's modulus, tensile strength, creep resistance, good tribo-corrosion resistance, improved electrical properties, and reduced thermal elongation.

Ceramics reinforcement particles such as silver nanoparticles ( $\mathrm{AgNp})$, calcium carbonate $\left(\mathrm{CaCO}_{3}\right)$, Alumina $\left(\mathrm{Al}_{2} \mathrm{O}_{3}\right)$ and silicon carbide $(\mathrm{SiC})$ are promising reinforcement particles with excellent functional properties. They are useful for important structural ceramics reinforcement and have proven to be promising reinforcement materials for hightemperature engineering applications because of their outstanding properties such as good corrosion resistance, high thermal conductivity, high stiffness, good chemical resistance, good electrical conductivity, remarkable wear resistance, high hardness, low density, high melting point and high elastic modulus [10-13]. They have found extensive applications in different industries for several applications such as diesel motor parts, gas turbines, industrial heat exchangers, high-temperature energy exchanger systems, hot gas filters, anti-abrasion parts in various atmospheres, medical implants and optical mirrors [14-18].

Different techniques have been proposed and implemented in improving the metallurgical properties of aluminium alloys [6,19-21]. The choice of modification technique used is selected based on the desired properties and area of application. Techniques such as powder blending, diffusion bonding, vapour deposition, liquid state processing, stir casting, spray deposition, friction stir processing, and squeeze casting have been investigated and recommended [22-25].

Stir casting has been demonstrated to be a promising technique for modifying the properties of Aluminium and its alloys. Stir casting is widely accepted as a promising technique for the manufacture of metal matrix composites. Its advantages over several other techniques are the easy mode of operation, flexibility, simplicity, applicability to large quantity production and cost-effective advantages [19,20,26-30].

The stir casting process is mainly used for the manufacturing of a particulate reinforced metal matrix composite (PMMC). The process involves the dispersion of reinforcement particles into the molten matrix melt and continuous stirring to achieve homogeneity and eliminate the entrapment of air bubbles. Before the addition of the reinforcement material into the mould, the molten metal matrix is usually subjected to degassing by a suitable medium because the molten metal matrix can react with atmospheric air and undergoes oxidation, thereby degrading the properties of the composite material [16,31-40].

Gallardo reported a higher yield and tensile strength for A12024 reinforced with AgNp when compared with the monolithic Al2024 [41]. Rosa-Hilda found out that the silver nanoparticles have a positive effect in refining the particle powder size and the crystallite size of the composite, thereby improving the mechanical properties and microhardness [42]. In the research investigation of Sosimi et al., they reported that the presence of $\mathrm{CaCO}_{3}$ contributes significantly to the wear behaviour [43]. The effect of silver nanoparticle (AgNp) mixed with calcium carbonate on impact, hardness, and tensile strength properties of aluminium 6063 was studied by Adefemi et al. They concluded that the magnitude of effect, tensile strength and hardness increased evidently with the increase in percentage weight fraction of the AgNps [44]. Research has shown that $\mathrm{CaCO}_{3}$ and $\mathrm{AgNp}$ can improve the mechanical properties of aluminium alloys. Despite this, research on the corrosion protection efficiency is still missing, especially long-term corrosion study.

In this research investigation, the aluminium metal matrix was produced using a combination of Alumina and silicon carbide reinforcement particles via the stir casting technique and the effect of the reinforcement and heat treatment on the corrosion property was examined. 


\section{Materials and Methods}

Aluminium alloy 6063 was used as the matrix material. The reinforcement consists of nano-silver particles and calcium carbonate as the binder. An amount of $300 \mathrm{~g}$ of nanosilver particles $(\mathrm{AgNp})$ was impregnated with $300 \mathrm{~g}$ of calcium carbonate $\left(\mathrm{CaCO}_{3}\right)$ and mixed thoroughly using a Heidolph RZR 20121 automatic stirring machine. The function of $\mathrm{CaCO}_{3}$ is to serve as a binder without altering the composition and properties of the $\mathrm{AgNp}$ and the base metal. The slurry was spread on plastic and left for six hours to solidify at atmospheric temperature and relative humidity. The dried mixture was ground into powder using a crucible and sieved through a $600 \mu \mathrm{m}$ mesh to a obtain fine and even particle size. The modified nano-silver particle ( $\mathrm{AgNp}$ ) and calcium carbonate were used to prepare a metal matrix composite of aluminium-nano-silver particles (Al-AgNp) by the stirred melting technique. Table 1 presents the mixing ratio used for this research investigation.

Table 1. Mixing ratio of base metal (AA6063) to reinforcements $\left(\mathrm{AgNp}\right.$ and $\left.\mathrm{CaCO}_{3}\right)$.

\begin{tabular}{|c|c|c|c|c|c|}
\hline \multirow[t]{2}{*}{ Sample } & \multirow[t]{2}{*}{ Mass of Al (g) } & \multicolumn{2}{|c|}{$\begin{array}{l}\text { Reinforcement Fraction } \\
\left(\mathrm{AgNp}+\mathrm{CaCO}_{3}\right)\end{array}$} & \multicolumn{2}{|c|}{$\begin{array}{l}\text { Reinforcement Fraction } \\
\qquad\left(\mathrm{CaCO}_{3}\right)\end{array}$} \\
\hline & & Mass (g) & $\%$ & Mass (g) & $\%$ \\
\hline$S_{1}$ & 980.00 & 20.00 & 2.00 & - & - \\
\hline$S_{2}$ & 960.00 & 40.00 & 4.00 & - & - \\
\hline $\mathrm{S}_{3}$ & 940.00 & 60.00 & 6.00 & - & - \\
\hline $\mathrm{S}_{4}$ & 980.00 & - & - & 20.00 & 2.00 \\
\hline $\mathrm{S}_{5}$ & 960.00 & - & - & 40.00 & 4.00 \\
\hline$S_{6}$ & 940.00 & - & - & 60.00 & 6.00 \\
\hline $\mathrm{S}_{\mathrm{C}}$ & 1000.00 & - & - & - & - \\
\hline
\end{tabular}

Each billet portion was preheated to $450{ }^{\circ} \mathrm{C}$ (to be able to incorporate the modified AgNp) before being finally melted at $750{ }^{\circ} \mathrm{C}$ in a crucible furnace. Amounts of $20 \mathrm{~g}, 40 \mathrm{~g}$ and $60 \mathrm{~g}$ of the modified $\mathrm{AgNp}$ were weighed and preheated at $100{ }^{\circ} \mathrm{C}$ before being incorporated into $980 \mathrm{~g}, 969 \mathrm{~g}$ and $940 \mathrm{~g}$ of melted aluminium billets, respectively. The mixture was thoroughly mixed at $180 \mathrm{rpm}$ for $10 \mathrm{~min}$ and poured into a cylindrical mould. These procedures were repeated for $\mathrm{Al}-\mathrm{CaCO}_{3}$ at the same specified percentage weight fraction as indicated in Table 1.

Each sample was cut into two equal parts. One part of each sample was selected for heat treatment. Heat treatment was carried out on the AMC billets to modify the metallurgical properties. The samples were heat-treated at $522^{\circ} \mathrm{C}\left(970{ }^{\circ} \mathrm{F}\right)$ and soaked for $60 \mathrm{~min}$ and followed by quenching in water for rapid cooling to prevent precipitation of the alloy elements on cooling. This results in the production of T4 temper.

A weight loss corrosion study was carried out on both heated and unheated samples using corrosive media of $\mathrm{HCl}$ (acidic medium) and $\mathrm{NaCl}$ (neutral condition) at three different levels of concentration. The corrosion analysis was carried out by measuring the weight loss of the samples in a corrosive media after different time durations. The samples were kept inside a corrosion chamber with a regulated temperature of $35^{\circ} \mathrm{C}$ and $100 \%$ relative humidity in accordance with ASTM B117-03 standards. The final representation of the samples is presented in Tables 2-6 for Aluminium metal matrix reinforced with $\mathrm{AgNp}+\mathrm{CaCO}_{3}$ (unheated), reinforced with $\mathrm{CaCO}_{3}$ (unheated), aluminium alloys (heattreated and unheated), reinforced with $\mathrm{AgNp}+\mathrm{CaCO}_{3}$ (heat-treated), and reinforced with $\mathrm{CaCO}_{3}$ (heat-treated). The samples were weighed on an electronic scale balance with an accuracy of $0.1 \mathrm{mg}$.

\section{Microstructural Evolution Characterisation}

Some selected samples $\left(S_{2}\right)$ from both corrosive media at a specific concentration were taken for microstructural analysis to investigate and compare the effect of different electrolytes $(\mathrm{NaCl}$ and $\mathrm{HCl})$ on the heat-treated composite materials. Optical microscopy 
was conducted using an Olympus BX51M. The Olympus BX51M was used to observe the microstructure of the samples. Digital output was captured and processed using Olympus Stream Essential software. The optical microscope was used to study the microstructural evolution of some selected samples $\left(\mathrm{S}_{2}\right)$ of corrosion behaviour of the aluminium-silver nanoparticle (AA6063/ AgNp/ $\mathrm{CaCO}_{3}$ ) matrix composite. Micrographs of the microstructural features at a specific concentration (0.10) at different electrolytes were captured and studied.

Table 2. Unheated $\mathrm{AgNp}+\mathrm{CaCO}_{3}$ sample notation.

\begin{tabular}{|c|c|c|c|}
\hline \multicolumn{4}{|c|}{ Unheated } \\
\hline S.N & Composite & Sample & Specimen Label \\
\hline 1 & $2 \% \mathrm{AgNp}+\mathrm{CaCO}_{3}$ & $\mathrm{~S}_{1}$ & $\begin{array}{c}\mathrm{S}_{1} \mathrm{NaCl} 0.10 \\
\mathrm{~S}_{1} \mathrm{NaCl} 0.15 \\
\mathrm{~S}_{1} \mathrm{NaCl} 0.20 \\
\mathrm{~S}_{1} \mathrm{HCl} 0.10 \\
\mathrm{~S}_{1} \mathrm{HCl} 0.15 \\
\mathrm{~S}_{1} \mathrm{HCl} 0.20\end{array}$ \\
\hline 2 & $4 \% \mathrm{AgNp}+\mathrm{CaCO}_{3}$ & $\mathrm{~S}_{2}$ & $\begin{array}{c}\mathrm{S}_{2} \mathrm{NaCl} 0.10 \\
\mathrm{~S}_{2} \mathrm{NaCl} 0.15 \\
\mathrm{~S}_{2} \mathrm{NaCl} 0.20 \\
\mathrm{~S}_{2} \mathrm{HCl} 0.10 \\
\mathrm{~S}_{2} \mathrm{HCl} 0.15 \\
\mathrm{~S}_{2} \mathrm{HCl} 0.20\end{array}$ \\
\hline 3 & $6 \% \mathrm{AgNp}+\mathrm{CaCO}_{3}$ & $\mathrm{~S}_{3}$ & $\begin{array}{c}\mathrm{S}_{3} \mathrm{NaCl} 0.10 \\
\mathrm{~S}_{3} \mathrm{NaCl} 0.15 \\
\mathrm{~S}_{3} \mathrm{NaCl} 0.20 \\
\mathrm{~S}_{3} \mathrm{HCl} 0.10 \\
\mathrm{~S}_{3} \mathrm{HCl} 0.15 \\
\mathrm{~S}_{3} \mathrm{HCl} 0.20\end{array}$ \\
\hline
\end{tabular}

Table 3. Unheated $\mathrm{CaCO}_{3}$ specimens with their labels and weight.

\begin{tabular}{|c|c|c|c|}
\hline \multicolumn{4}{|c|}{ Unheated } \\
\hline S.N & Composite & Sample & Specimen Label \\
\hline 4 & $2 \% \mathrm{CaCO}_{3}$ & $\mathrm{~S}_{4}$ & $\begin{array}{c}\mathrm{S}_{4} \mathrm{NaCl} 0.10 \\
\mathrm{~S}_{4} \mathrm{NaCl} 0.15 \\
\mathrm{~S}_{4} \mathrm{NaCl} 0.20 \\
\mathrm{~S}_{4} \mathrm{HCl} 0.10 \\
\mathrm{~S}_{4} \mathrm{HCl} 0.15 \\
\mathrm{~S}_{4} \mathrm{HCl} 0.20\end{array}$ \\
\hline 5 & $4 \% \mathrm{CaCO}_{3}$ & $\mathrm{~S}_{5}$ & 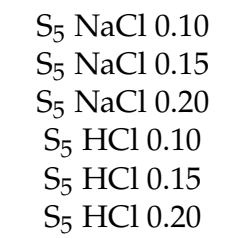 \\
\hline 6 & $6 \% \mathrm{CaCO}_{3}$ & $\mathrm{~S}_{6}$ & $\begin{array}{c}\mathrm{S}_{6} \mathrm{NaCl} 0.10 \\
\mathrm{~S}_{6} \mathrm{NaCl} 0.15 \\
\mathrm{~S}_{6} \mathrm{NaCl} 0.20 \\
\mathrm{~S}_{6} \mathrm{HCl} 0.10 \\
\mathrm{~S}_{6} \mathrm{HCl} 0.15 \\
\mathrm{~S}_{6} \mathrm{HCl} 0.20\end{array}$ \\
\hline
\end{tabular}


Table 4. Labels and weight of unheated and heat-treated aluminium alloy control specimens.

\begin{tabular}{|c|c|c|c|}
\hline \multicolumn{4}{|c|}{ Untreated } \\
\hline S.N & Composite & Sample & Specimen Label \\
\hline 7 & $100 \%$ AA6063 & $\mathrm{C}$ & $\begin{array}{l}\mathrm{C} \mathrm{NaCl} 0.10 \\
\mathrm{C} \mathrm{NaCl} 0.15 \\
\mathrm{C} \mathrm{NaCl} 0.20 \\
\mathrm{C} \mathrm{HCl} 0.10 \\
\mathrm{C} \mathrm{HCl} 0.15 \\
\mathrm{C} \mathrm{HCl} 0.20\end{array}$ \\
\hline \multicolumn{4}{|c|}{ Heat Treated } \\
\hline 8 & $100 \%$ AA6063 & $\mathrm{C}_{\mathrm{T}}$ & $\begin{array}{l}\mathrm{C}_{\mathrm{T}} \mathrm{NaCl} 0.10 \\
\mathrm{C}_{\mathrm{T}} \mathrm{NaCl} 0.15 \\
\mathrm{C}_{\mathrm{T}} \mathrm{NaCl} 0.20 \\
\mathrm{C}_{\mathrm{T}} \mathrm{HCl} 0.10 \\
\mathrm{C}_{\mathrm{T}} \mathrm{HCl} 0.15 \\
\mathrm{C}_{\mathrm{T}} \mathrm{HCl} 0.20\end{array}$ \\
\hline
\end{tabular}

Table 5. Labels and weight of heat-treated $\mathrm{AgNp}+\mathrm{CaCO}_{3}$ specimens.

\begin{tabular}{|c|c|c|c|}
\hline \multicolumn{4}{|c|}{ Heat-Treated } \\
\hline S.N & Composite & Sample & Specimen Label \\
\hline 9 & $2 \% \mathrm{AgNp}+\mathrm{CaCO}_{3}$ & $\mathrm{~S}_{\mathrm{T} 1}$ & $\begin{array}{l}\mathrm{S}_{\mathrm{T} 1} \mathrm{NaCl} 0.10 \\
\mathrm{~S}_{\mathrm{T} 1} \mathrm{NaCl} 0.15 \\
\mathrm{~S}_{\mathrm{T} 1} \mathrm{NaCl} 0.20 \\
\mathrm{~S}_{\mathrm{T} 1} \mathrm{HCl} 0.10 \\
\mathrm{~S}_{\mathrm{T} 1} \mathrm{HCl} 0.15 \\
\mathrm{~S}_{\mathrm{T} 1} \mathrm{HCl} 0.20\end{array}$ \\
\hline 10 & $4 \% \mathrm{AgNp}+\mathrm{CaCO}_{3}$ & $\mathrm{~S}_{\mathrm{T} 2}$ & $\begin{array}{l}\mathrm{S}_{\mathrm{T} 2} \mathrm{NaCl} 0.10 \\
\mathrm{~S}_{\mathrm{T} 2} \mathrm{NaCl} 0.15 \\
\mathrm{~S}_{\mathrm{T} 2} \mathrm{NaCl} 0.20 \\
\mathrm{~S}_{\mathrm{T} 2} \mathrm{HCl} 0.10 \\
\mathrm{~S}_{\mathrm{T} 2} \mathrm{HCl} 0.15 \\
\mathrm{~S}_{\mathrm{T} 2} \mathrm{HCl} 0.20\end{array}$ \\
\hline 11 & $6 \% \mathrm{AgNp}+\mathrm{CaCO}_{3}$ & $\mathrm{~S}_{\mathrm{T} 3}$ & $\begin{array}{l}\mathrm{S}_{\mathrm{T} 3} \mathrm{NaCl} 0.10 \\
\mathrm{~S}_{\mathrm{T} 3} \mathrm{NaCl} 0.15 \\
\mathrm{~S}_{\mathrm{T} 3} \mathrm{NaCl} 0.20 \\
\mathrm{~S}_{\mathrm{T} 3} \mathrm{HCl} 0.10 \\
\mathrm{~S}_{\mathrm{T} 3} \mathrm{HCl} 0.15 \\
\mathrm{~S}_{\mathrm{T} 3} \mathrm{HCl} 0.20\end{array}$ \\
\hline
\end{tabular}

Table 6. Labels and weight of heat-treated $\mathrm{CaCO}_{3}$ specimens.

\begin{tabular}{|c|c|c|c|}
\hline \multicolumn{4}{|c|}{ Heat Treated } \\
\hline S.N & Composite & Sample & Specimen Label \\
\hline 12 & $2 \% \mathrm{CaCO}_{3}$ & $\mathrm{~S}_{\mathrm{T} 4}$ & $\begin{array}{c}\mathrm{S}_{\mathrm{T} 4} \mathrm{NaCl} 0.10 \\
\mathrm{~S}_{\mathrm{T} 4} \mathrm{NaCl} 0.15 \\
\mathrm{~S}_{\mathrm{T} 4} \mathrm{NaCl} 0.20 \\
\mathrm{~S}_{\mathrm{T} 4} \mathrm{HCl} 0.10 \\
\mathrm{~S}_{\mathrm{T} 4} \mathrm{HCl} 0.15 \\
\mathrm{~S}_{\mathrm{T} 4} \mathrm{HCl} 0.20\end{array}$ \\
\hline 13 & $4 \% \mathrm{CaCO}_{3}$ & $\mathrm{~S}_{\mathrm{T} 5}$ & $\begin{array}{c}\mathrm{S}_{\mathrm{T} 5} \mathrm{NaCl} 0.10 \\
\mathrm{~S}_{\mathrm{T} 5} \mathrm{NaCl} 0.15 \\
\mathrm{~S}_{\mathrm{T} 5} \mathrm{NaCl} 0.20 \\
\mathrm{~S}_{\mathrm{T} 5} \mathrm{HCl} 0.10 \\
\mathrm{~S}_{\mathrm{T} 5} \mathrm{HCl} 0.15 \\
\mathrm{~S}_{\mathrm{T} 5} \mathrm{HCl} 0.20\end{array}$ \\
\hline
\end{tabular}


Table 6. Cont.

\begin{tabular}{cccc}
\hline S.N & \multicolumn{2}{c}{ Composite } & \\
& & Sample & Specimen Label \\
\hline & & $\mathrm{S}_{\mathrm{T} 6} \mathrm{NaCl} 0.10$ \\
& & & $\mathrm{~S}_{\mathrm{T} 6} \mathrm{NaCl} 0.15$ \\
& & & $\mathrm{~S}_{\mathrm{T} 6} \mathrm{NaCl} 0.20$ \\
& & $\mathrm{~S}_{\mathrm{T} 6}$ & $\mathrm{~S}_{\mathrm{T} 6} \mathrm{HCl} 0.10$ \\
& & $\mathrm{~S}_{\mathrm{T} 6} \mathrm{HCl} 0.15$ \\
& & $\mathrm{~S}_{\mathrm{T} 6} \mathrm{HCl} 0.20$ \\
\hline
\end{tabular}

\section{Results}

The corrosion experiment lasted for 30 days, with data collected every $72 \mathrm{~h}$. The results obtained from the corrosion experiment was presented and discussed in this chapter. The result of the corrosion experiment conducted on unheated AA6063 specimens $S_{1}, S_{2}$ and $S_{3}$ reinforced with $\mathrm{AgNp}+\mathrm{CaCO}_{3}$ at $2 \%, 4 \%$ and $6 \%$, respectively, for 30 days in different concentrations of $\mathrm{HCl}$ and $\mathrm{NaCl}$ is presented in Table 7. The histogram distribution for the weight loss is illustrated in Figures 1-3, respectively. The result of specimens $S_{4}, S_{5}$, and $S_{6}$ reinforced with $\mathrm{CaCO}_{3}$ only at $2 \%, 4 \%$, and $6 \%$, respectively, soaked in the same media for the period, is shown in Table 8 and Figures 4-6 are the histogram distribution for the weight loss.

Table 7. Specimens $S_{1}, S_{2}$ and $S_{3}$ weight reduction in $\mathrm{HCl}$ and $\mathrm{NaCl}$.

\begin{tabular}{|c|c|c|c|c|c|c|}
\hline \multirow{2}{*}{ S.N } & \multirow{2}{*}{ Composite $\left(\mathrm{AgNp}+\mathrm{CaCO}_{3}\right)$} & \multirow{2}{*}{ Specimen Label } & \multicolumn{4}{|c|}{ Specimen Weight Reduction $\left(\mathrm{g} / \mathrm{cm}^{2}\right)$} \\
\hline & & & Day 3 & Day 12 & Day 21 & Day 30 \\
\hline \multirow{6}{*}{1} & \multirow{6}{*}{$S_{1} 2 \%$} & $\mathrm{~S}_{1} \mathrm{NaCl} 0.10$ & 0.15 & 0.55 & 0.92 & 1.42 \\
\hline & & $\mathrm{S}_{1} \mathrm{NaCl} 0.15$ & 0.06 & 0.28 & 0.58 & 1.04 \\
\hline & & $\mathrm{S}_{1} \mathrm{NaCl} 0.20$ & 0.08 & 0.28 & 0.47 & 0.72 \\
\hline & & $\mathrm{S}_{1} \mathrm{HCl} 0.10$ & 0.07 & 0.31 & 0.53 & 0.78 \\
\hline & & $\mathrm{S}_{1} \mathrm{HCl} 0.15$ & 0.09 & 0.42 & 0.70 & 1.09 \\
\hline & & $\mathrm{S}_{1} \mathrm{HCl} 0.20$ & 0.09 & 0.30 & 0.46 & 0.70 \\
\hline \multirow{6}{*}{2} & \multirow{6}{*}{$\mathrm{S}_{2} 4 \%$} & $\mathrm{~S}_{2} \mathrm{NaCl} 0.10$ & 0.10 & 0.33 & 0.53 & 0.81 \\
\hline & & $\mathrm{S}_{2} \mathrm{NaCl} 0.15$ & 0.06 & 0.32 & 0.57 & 0.91 \\
\hline & & $\mathrm{S}_{2} \mathrm{NaCl} 0.20$ & 0.03 & 0.11 & 0.20 & 0.31 \\
\hline & & $\mathrm{S}_{2} \mathrm{HCl} 0.10$ & 0.34 & 0.66 & 0.97 & 1.45 \\
\hline & & $\mathrm{S}_{2} \mathrm{HCl} 0.15$ & 0.11 & 0.44 & 0.72 & 1.06 \\
\hline & & $\mathrm{S}_{2} \mathrm{HCl} 0.20$ & 0.13 & 0.58 & 0.98 & 1.53 \\
\hline \multirow{6}{*}{3} & \multirow{6}{*}{$\mathrm{S}_{3} 6 \%$} & $\mathrm{~S}_{3} \mathrm{NaCl} 0.10$ & 0.13 & 0.48 & 0.79 & 1.24 \\
\hline & & $\mathrm{S}_{3} \mathrm{NaCl} 0.15$ & 0.13 & 0.55 & 0.98 & 1.55 \\
\hline & & $\mathrm{S}_{3} \mathrm{NaCl} 0.20$ & 0.10 & 0.39 & 0.68 & 1.02 \\
\hline & & $\mathrm{S}_{3} \mathrm{HCl} 0.10$ & 0.09 & 0.49 & 0.86 & 1.30 \\
\hline & & $\mathrm{S}_{3} \mathrm{HCl} 0.15$ & 0.55 & 0.82 & 1.10 & 1.45 \\
\hline & & $\mathrm{S}_{3} \mathrm{HCl} 0.20$ & 0.11 & 0.42 & 0.69 & 1.05 \\
\hline
\end{tabular}




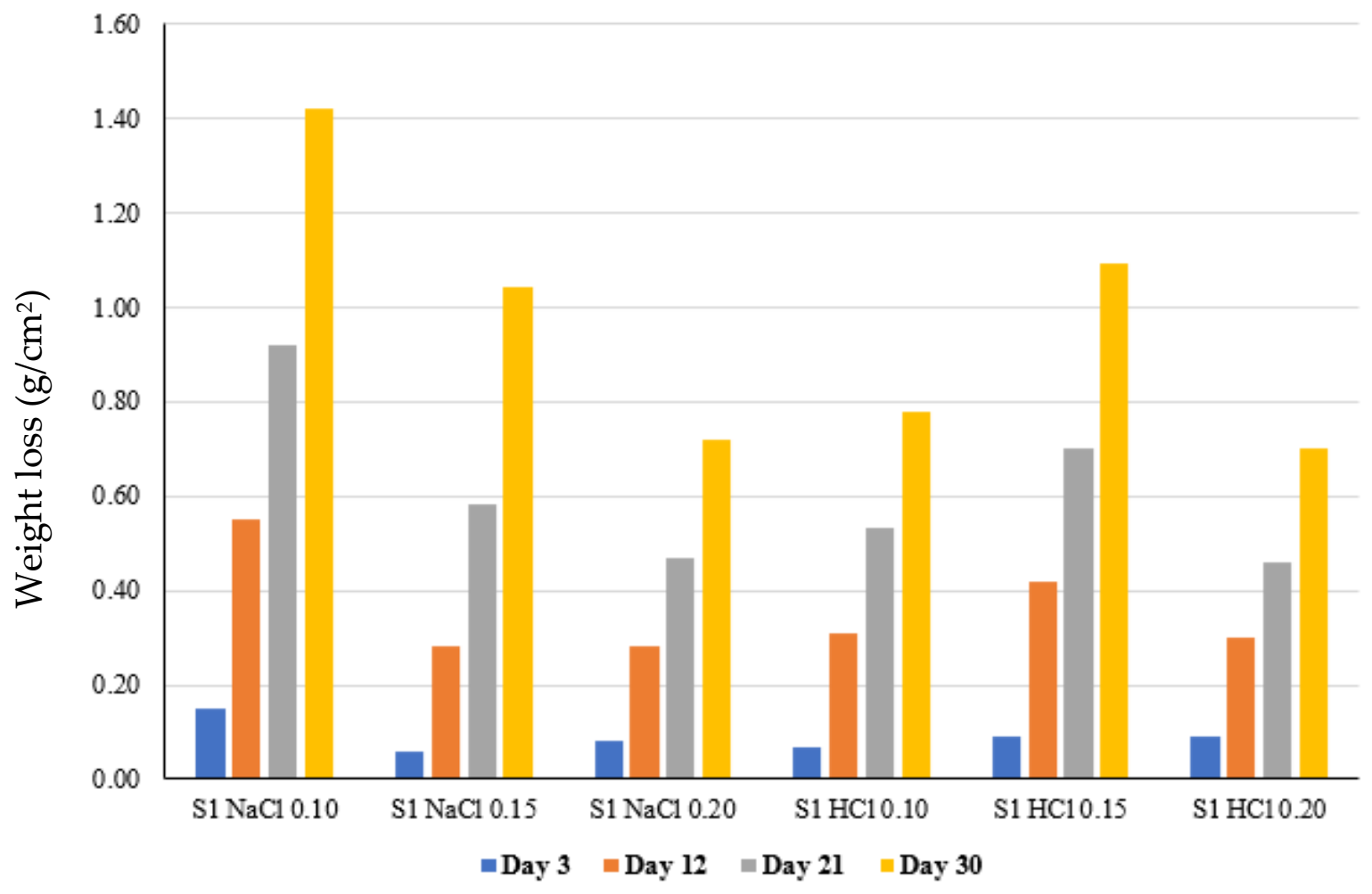

Figure 1. Effect of $\mathrm{AgNp}+\mathrm{CaCO}_{3}$ on corrosion behaviour of $\mathrm{S}_{1}(2 \%)$.

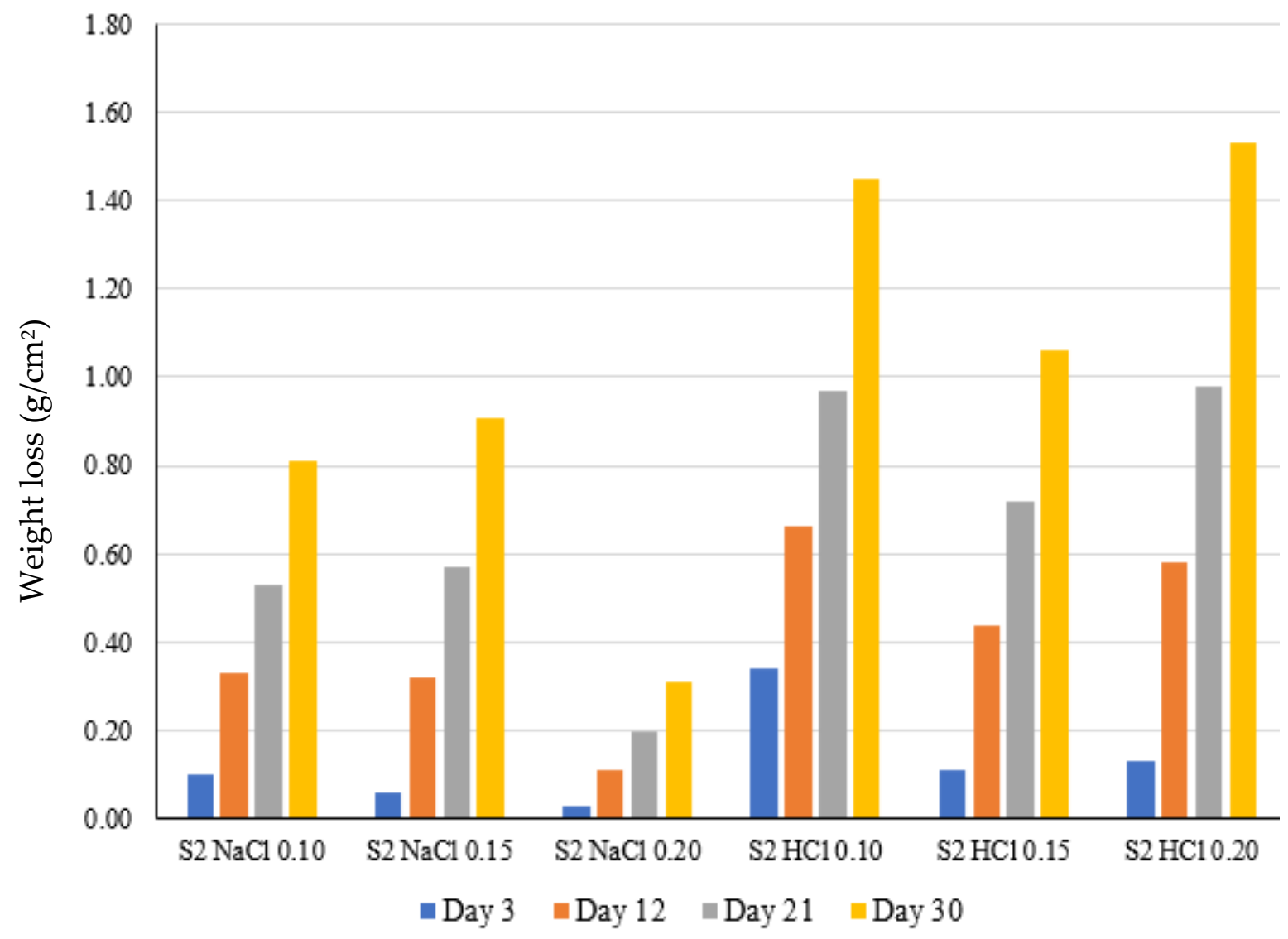

Figure 2. Effect of $\mathrm{AgNp}+\mathrm{CaCO}_{3}$ on corrosion behaviour of $\mathrm{S}_{2}(4 \%)$. 


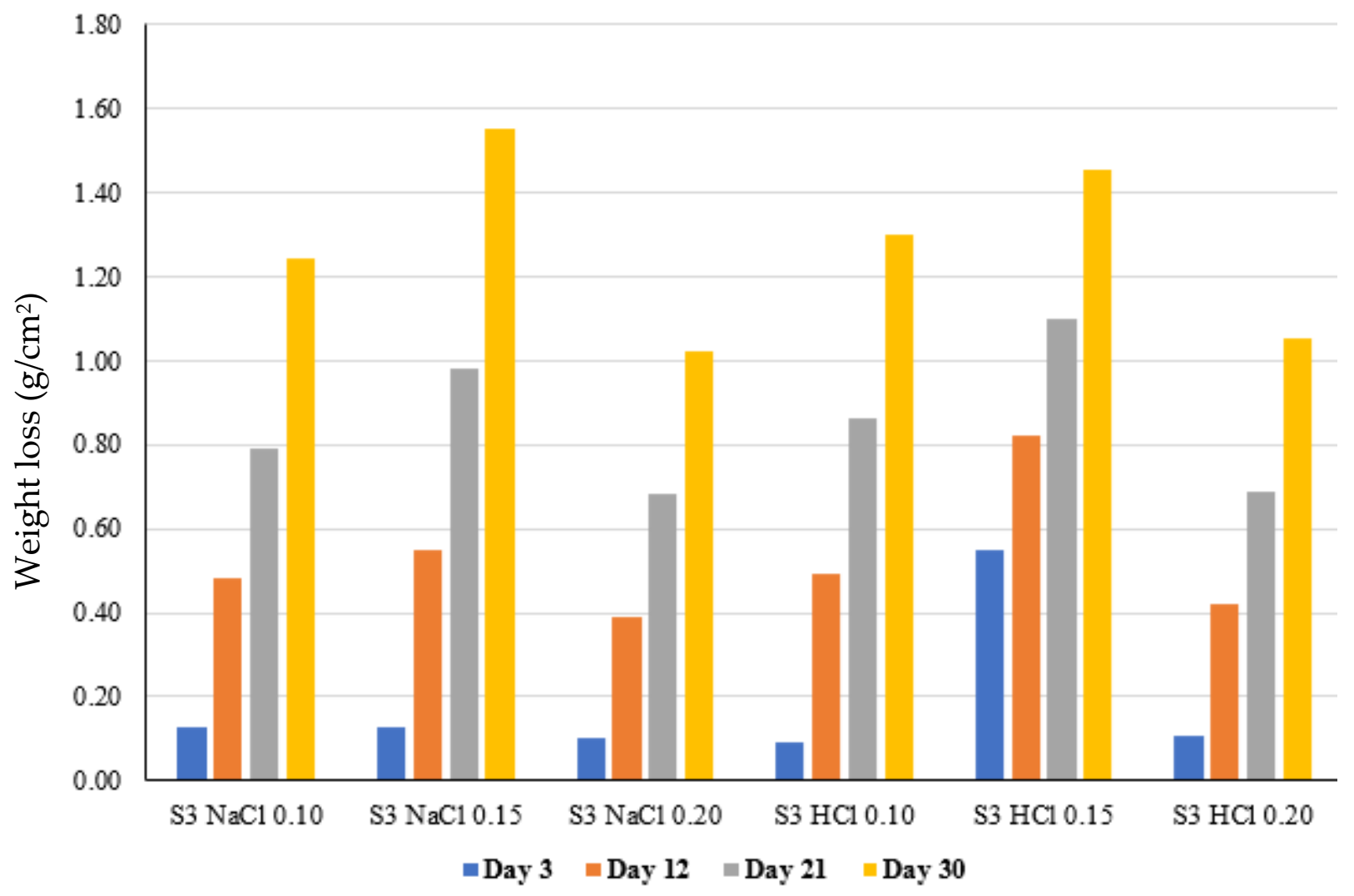

Figure 3. Effect of $\mathrm{AgNp}+\mathrm{CaCO}_{3}$ on corrosion behaviour of $\mathrm{S}_{3}(6 \%)$.

Table 8. Specimen $\mathrm{S}_{4}, \mathrm{~S}_{5}$ and $\mathrm{S}_{6}$ weight reduction in $\mathrm{HCl}$ and $\mathrm{NaCl}$.

\begin{tabular}{|c|c|c|c|c|c|c|}
\hline \multirow{2}{*}{ S.N } & \multirow{2}{*}{ Composite $\left(\mathrm{CaCO}_{3}\right)$} & \multirow{2}{*}{ Specimen Label } & \multicolumn{4}{|c|}{ Specimen Weight Reduction (g) } \\
\hline & & & Day 3 & Day 12 & Day 21 & Day 30 \\
\hline \multirow{6}{*}{4} & \multirow{6}{*}{$\mathrm{S}_{4} 2 \%$} & $\mathrm{~S}_{4} \mathrm{NaCl} 0.10$ & 0.13 & 0.47 & 0.77 & 1.19 \\
\hline & & $\mathrm{S}_{4} \mathrm{NaCl} 0.15$ & 0.09 & 0.33 & 0.54 & 0.82 \\
\hline & & $\mathrm{S}_{4} \mathrm{NaCl} 0.20$ & 0.11 & 0.42 & 0.68 & 1.06 \\
\hline & & $\mathrm{S}_{4} \mathrm{HCl} 0.10$ & 0.12 & 0.61 & 1.04 & 1.59 \\
\hline & & $\mathrm{S}_{4} \mathrm{HCl} 0.15$ & 0.13 & 0.50 & 0.82 & 1.24 \\
\hline & & $\mathrm{S}_{4} \mathrm{HCl} 0.20$ & 0.31 & 0.61 & 0.88 & 1.38 \\
\hline \multirow{6}{*}{5} & \multirow{6}{*}{$\mathrm{S}_{5} 4 \%$} & $\mathrm{~S}_{5} \mathrm{NaCl} 0.10$ & 0.62 & 1.01 & 1.39 & 1.86 \\
\hline & & $\mathrm{S}_{5} \mathrm{NaCl} 0.15$ & 0.07 & 0.27 & 0.44 & 0.67 \\
\hline & & $\mathrm{S}_{5} \mathrm{NaCl} 0.20$ & 0.07 & 0.32 & 0.57 & 0.89 \\
\hline & & $\mathrm{S}_{5} \mathrm{HCl} 0.10$ & 0.09 & 0.36 & 0.58 & 0.89 \\
\hline & & $\mathrm{S}_{5} \mathrm{HCl} 0.15$ & 0.10 & 0.30 & 0.46 & 0.69 \\
\hline & & $\mathrm{S}_{5} \mathrm{HCl} 0.20$ & 0.23 & 0.93 & 1.56 & 2.34 \\
\hline \multirow{6}{*}{6} & \multirow{6}{*}{$\mathrm{S}_{6} 6 \%$} & $\mathrm{~S}_{6} \mathrm{NaCl} 0.10$ & 0.10 & 0.32 & 0.58 & 0.90 \\
\hline & & $\mathrm{S}_{6} \mathrm{NaCl} 0.15$ & 0.02 & 0.09 & 0.16 & 0.27 \\
\hline & & $\mathrm{S}_{6} \mathrm{NaCl} 0.20$ & 0.05 & 0.15 & 0.26 & 0.41 \\
\hline & & $\mathrm{S}_{6} \mathrm{HCl} 0.10$ & 0.11 & 0.44 & 0.74 & 1.13 \\
\hline & & $\mathrm{S}_{6} \mathrm{HCl} 0.15$ & 0.11 & 0.34 & 0.61 & 0.91 \\
\hline & & $\mathrm{S}_{6} \mathrm{HCl} 0.20$ & 0.10 & 0.35 & 0.66 & 1.00 \\
\hline
\end{tabular}




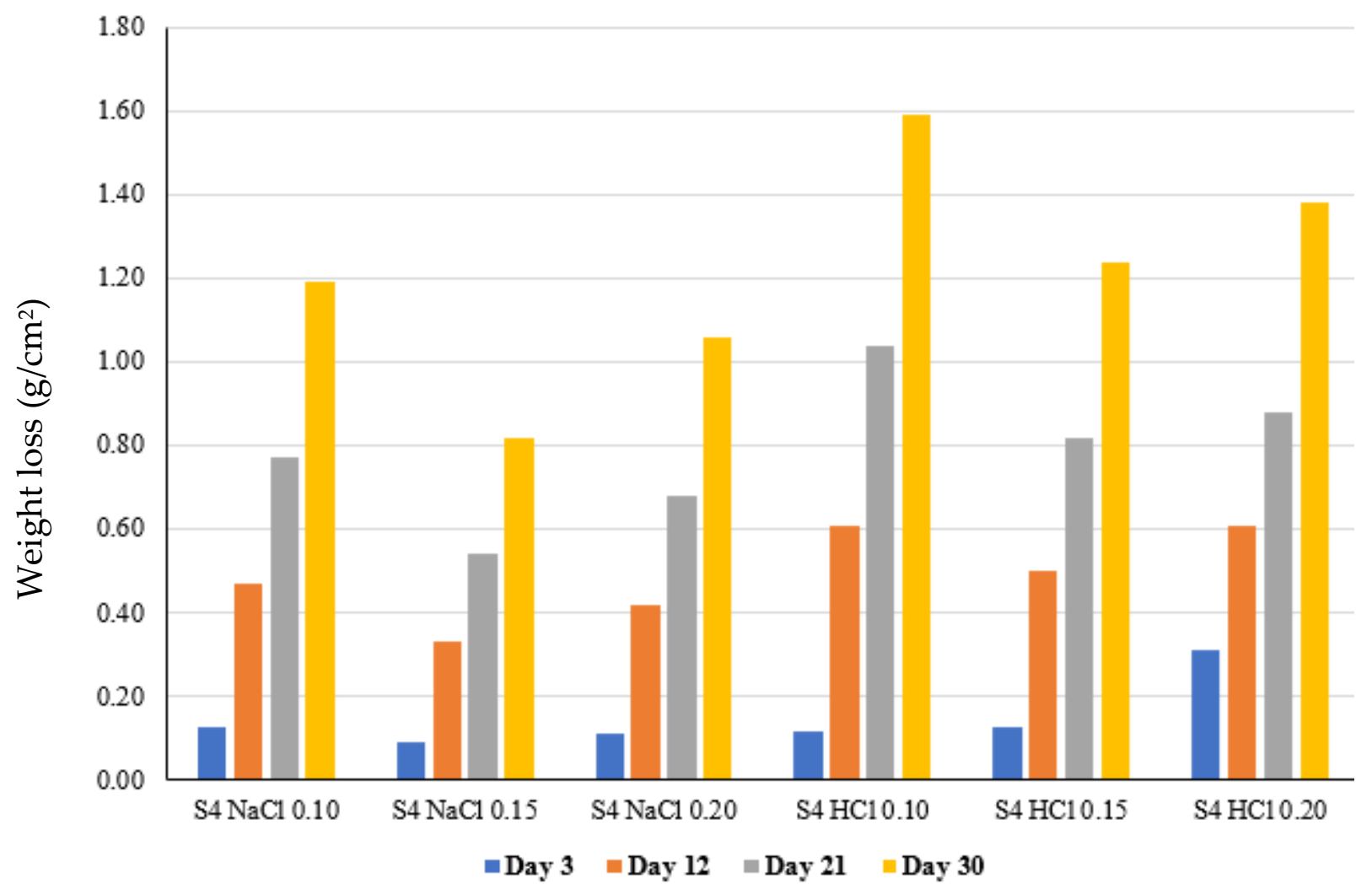

Figure 4. Effect of $\mathrm{CaCO}_{3}$ on corrosion behaviour of $\mathrm{S}_{4}(2 \%)$.

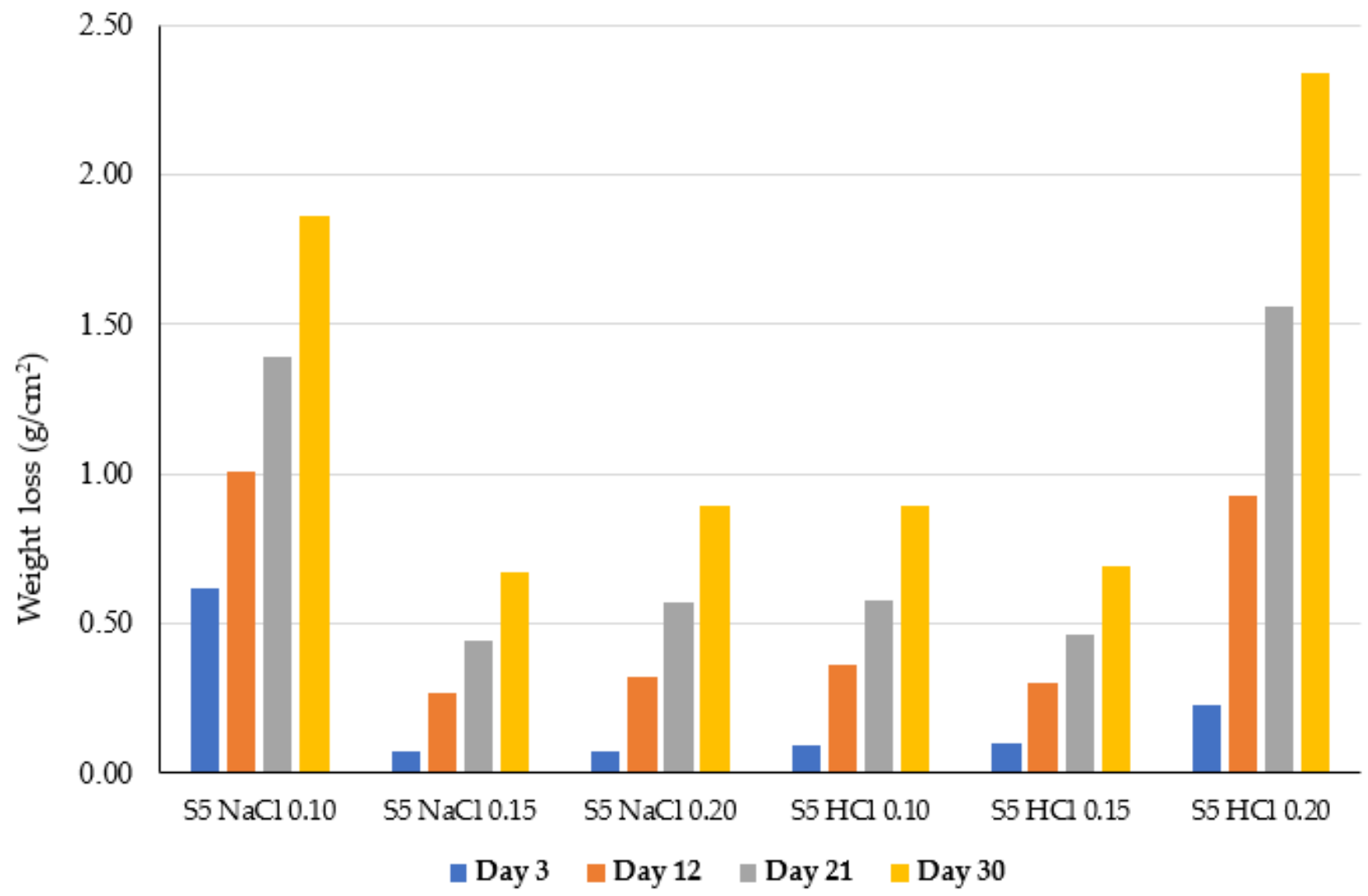

Figure 5. Effect of $\mathrm{CaCO}_{3}$ on corrosion behaviour of $\mathrm{S}_{5}(4 \%)$. 


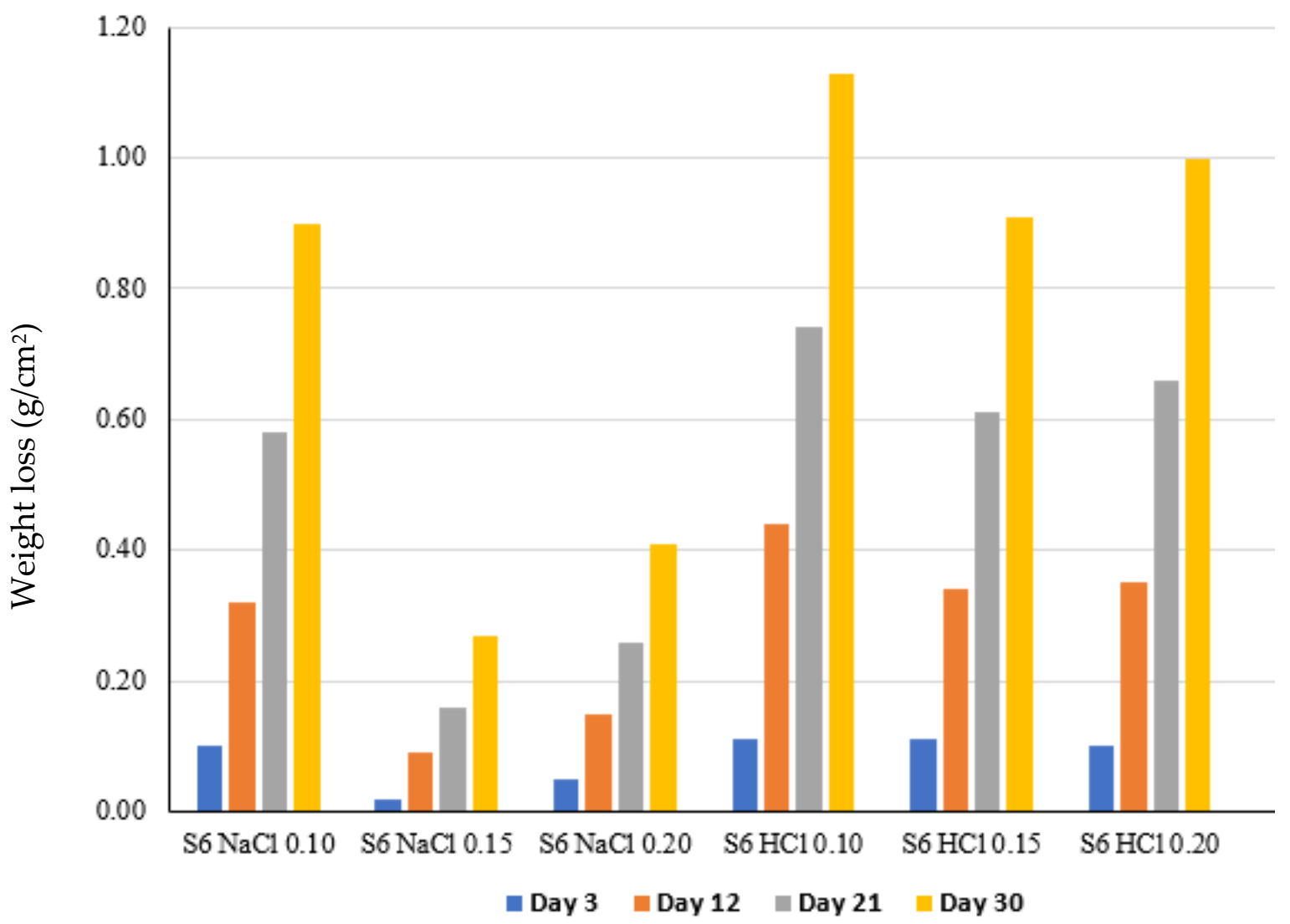

Figure 6. Effect of $\mathrm{CaCO}_{3}$ on corrosion behaviour of $\mathrm{S}_{6}(6 \%)$.

Figures 1-3 showed the corrosion behaviour of reinforced AA6063 specimens S1, $\mathrm{S} 2$ and $\mathrm{S} 3$ with $2 \%, 4 \%$ and $6 \% \mathrm{AgNp}+\mathrm{CaCO}_{3}$, respectively. Figure 1 reveals that the corrosion rate is fastest in $\mathrm{S}_{1} \mathrm{NaCl}-0.10$ soaked in $0.1 \mathrm{M}$ of Sodium Chloride, followed by $\mathrm{S}_{1-}$ $\mathrm{HCl}-0.15$ soaked in $0.15 \mathrm{M}$ of Hydrochloric Acid and $\mathrm{S}_{1} \mathrm{NaCl}-0.15$. The rate of corrosion in $\mathrm{S}_{1} \mathrm{NaCl}-0.20, \mathrm{~S}_{1} \mathrm{HCl}-0.10$ and $\mathrm{S}_{1} \mathrm{HCl}-0.20$ is the same, and the weight loss in the specimens are almost the same value $(0.72 \mathrm{~g}, 0.78 \mathrm{~g}$ and $0.70 \mathrm{~g}$, respectively) but lower than that of the other three specimens. Increasing the reinforcement particles to $4 \%$, as shown in Figure 2, reduced the corrosion rate in all the tested specimens except in $\mathrm{S}_{2} \mathrm{HCl}-0.10$ and $\mathrm{S}_{2} \mathrm{HCl}-0.20$, where the weight loss increased by $86 \%$ and $123 \%$, respectively. Figure 3 reveals another pattern as the composite was increased to $6 \%$; corrosion rate and weight loss in all the tested specimens increased significantly except in $\mathrm{S}_{2} \mathrm{HCl}-0.20$ where the weight loss was reduced by $31 \%$. Overall, the weight loss for all the coating increases with an increase in the exposure time. This shows that the materials fail to form a substantial protective layer in both media needed to inhibit the corrosion rate [45].

Figures 4-6 show the corrosion behaviour of reinforced AA6063 specimens $\mathrm{S}_{4}, \mathrm{~S}_{5}$, and $\mathrm{S}_{6}$ with $2 \%, 4 \%$ and $6 \% \mathrm{CaCO}_{3}$, respectively, for 30 days.

It is revealed in Figure 4 that the addition of $2 \% \mathrm{CaCO}_{3}$ as a composite to AA6063 increased the corrosion rate in all the samples. $\mathrm{S}_{4} \mathrm{HCl}-0.10$ has the highest weight reduction $(1.59 \mathrm{~g})$, while $\mathrm{S}_{4} \mathrm{NaCl}-0.15$ experiences the lowest reduction in weight. Figure 5 also reveals that the corrosion rate was reduced in all the specimens when the composite was increased to $4 \%$, except in $\mathrm{S}_{5} \mathrm{HCl}-0.20$ where the weight loss increased by $70 \%$. Figure 6 revealed that the corrosion rate reduced drastically further in all the specimens when reinforced with $6 \% \mathrm{CaCO}_{3}$, except in specimens $\mathrm{S}_{6} \mathrm{HCl}-0.10$ and $\mathrm{S}_{6} \mathrm{HCl}-0.15$ where weight loss increased again by $27 \%$ and $32 \%$, respectively.

Table 9 shows the results of the corrosion experiment conducted on heat-treated AA6063 specimens $\mathrm{S}_{\mathrm{T} 1}, \mathrm{~S}_{\mathrm{T} 2}$ and $\mathrm{S}_{\mathrm{T} 3}$ with $\mathrm{AgNp}+\mathrm{CaCO}_{3}$ composites at $2 \%, 4 \%$, and $6 \%$, respectively, soaked in $0.1 \mathrm{M}, 0.15 \mathrm{M}$ and $0.2 \mathrm{M} \mathrm{HCl}$ and $\mathrm{NaCl}$ for 30 days. Table 9 
presented the result of specimens $\mathrm{S}_{4}, \mathrm{~S}_{5}$ and $\mathrm{S}_{6}$ reinforced with $\mathrm{CaCO}_{3}$ only at $2 \%, 4 \%$ and $6 \%$, respectively, and soaked in the same media for 30 days, and their graphical representations are presented in Figures 7-9, respectively.

Table 9. Specimen $\mathrm{S}_{\mathrm{T} 1}, \mathrm{~S}_{\mathrm{T} 2}$ and $\mathrm{S}_{\mathrm{T} 3}$ weight reduction in $\mathrm{HCl}$ and $\mathrm{NaCl}$.

\begin{tabular}{|c|c|c|c|c|c|c|}
\hline \multirow{2}{*}{ S.N } & \multirow{2}{*}{ Composite $\left(\mathrm{AgNp}+\mathrm{CaCO}_{3}\right)$} & \multirow{2}{*}{ Specimen Label } & \multicolumn{4}{|c|}{ Specimen Weight Reduction (g) } \\
\hline & & & Day 3 & Day 12 & Day 21 & Day 30 \\
\hline \multirow{6}{*}{7} & \multirow{6}{*}{$\mathrm{S}_{\mathrm{T} 1} 2 \%$} & $\mathrm{~S}_{\mathrm{T} 1} \mathrm{NaCl} 0.10$ & 0.08 & 0.25 & 0.43 & 0.62 \\
\hline & & $\mathrm{S}_{\mathrm{T} 1} \mathrm{NaCl} 0.15$ & 0.06 & 0.21 & 0.36 & 0.55 \\
\hline & & $\mathrm{S}_{\mathrm{T} 1} \mathrm{NaCl} 0.20$ & 0.07 & 0.30 & 0.48 & 0.73 \\
\hline & & $\mathrm{S}_{\mathrm{T} 1} \mathrm{HCl} 0.10$ & 0.07 & 0.32 & 0.51 & 0.74 \\
\hline & & $\mathrm{S}_{\mathrm{T} 1} \mathrm{HCl} 0.15$ & 0.11 & 0.26 & 0.43 & 0.63 \\
\hline & & $\mathrm{S}_{\mathrm{T} 1} \mathrm{HCl} 0.20$ & 0.08 & 0.30 & 0.52 & 0.75 \\
\hline \multirow{6}{*}{8} & \multirow{6}{*}{$\mathrm{S}_{\mathrm{T} 2} 4 \%$} & $\mathrm{~S}_{\mathrm{T} 2} \mathrm{NaCl} 0.10$ & 0.07 & 0.22 & 0.37 & 0.96 \\
\hline & & $\mathrm{S}_{\mathrm{T} 2} \mathrm{NaCl} 0.15$ & 0.03 & 0.22 & 0.37 & 0.58 \\
\hline & & $\mathrm{S}_{\mathrm{T} 2} \mathrm{NaCl} 0.20$ & 0.08 & 0.18 & 0.56 & 0.99 \\
\hline & & $\mathrm{S}_{\mathrm{T} 2} \mathrm{HCl} 0.10$ & 0.05 & 0.20 & 0.28 & 0.42 \\
\hline & & $\mathrm{S}_{\mathrm{T} 2} \mathrm{HCl} 0.15$ & 0.08 & 0.27 & 0.45 & 0.72 \\
\hline & & $\mathrm{S}_{\mathrm{T} 2} \mathrm{HCl} 0.20$ & 0.07 & 0.30 & 0.47 & 0.72 \\
\hline \multirow{6}{*}{9} & \multirow{6}{*}{$\mathrm{S}_{\mathrm{T} 3} 6 \%$} & $\mathrm{~S}_{\mathrm{T} 3} \mathrm{NaCl} 0.10$ & 0.07 & 0.27 & 0.44 & 0.70 \\
\hline & & $\mathrm{S}_{\mathrm{T} 3} \mathrm{NaCl} 0.15$ & 0.06 & 0.31 & 0.55 & 0.86 \\
\hline & & $\mathrm{S}_{\mathrm{T} 3} \mathrm{NaCl} 0.20$ & 0.11 & 0.36 & 0.59 & 0.98 \\
\hline & & $\mathrm{S}_{\mathrm{T} 3} \mathrm{HCl} 0.10$ & 0.14 & 1.23 & 3.09 & 9.61 \\
\hline & & $\mathrm{S}_{\mathrm{T} 3} \mathrm{HCl} 0.15$ & 0.06 & 0.11 & 0.17 & 0.25 \\
\hline & & $\mathrm{S}_{\mathrm{T} 3} \mathrm{HCl} 0.20$ & 0.06 & 0.22 & 0.36 & 0.54 \\
\hline
\end{tabular}

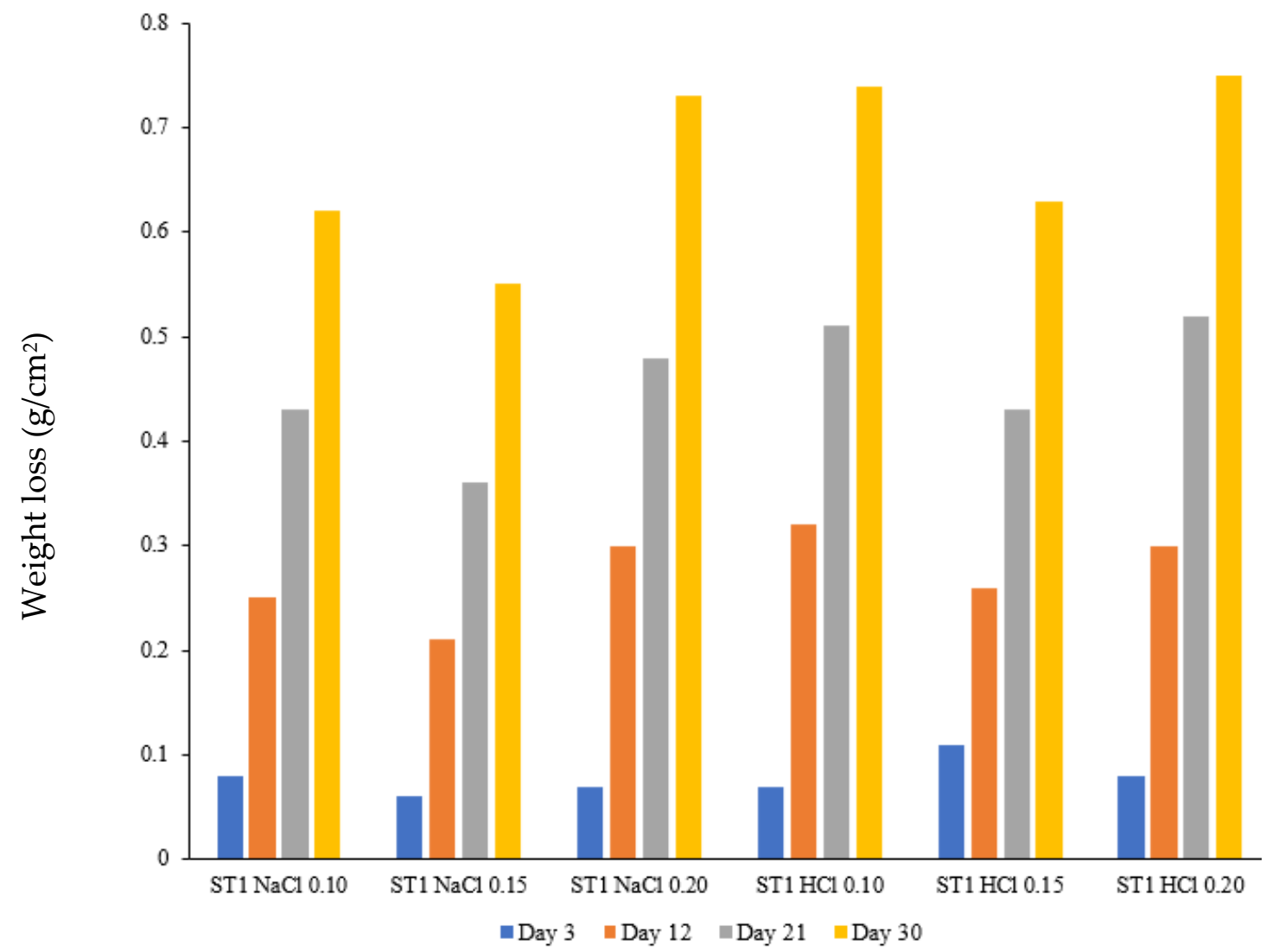

Figure 7. Effect of heat treatment on corrosion behaviour of $\mathrm{S}_{\mathrm{T} 1}(2 \%)$. 


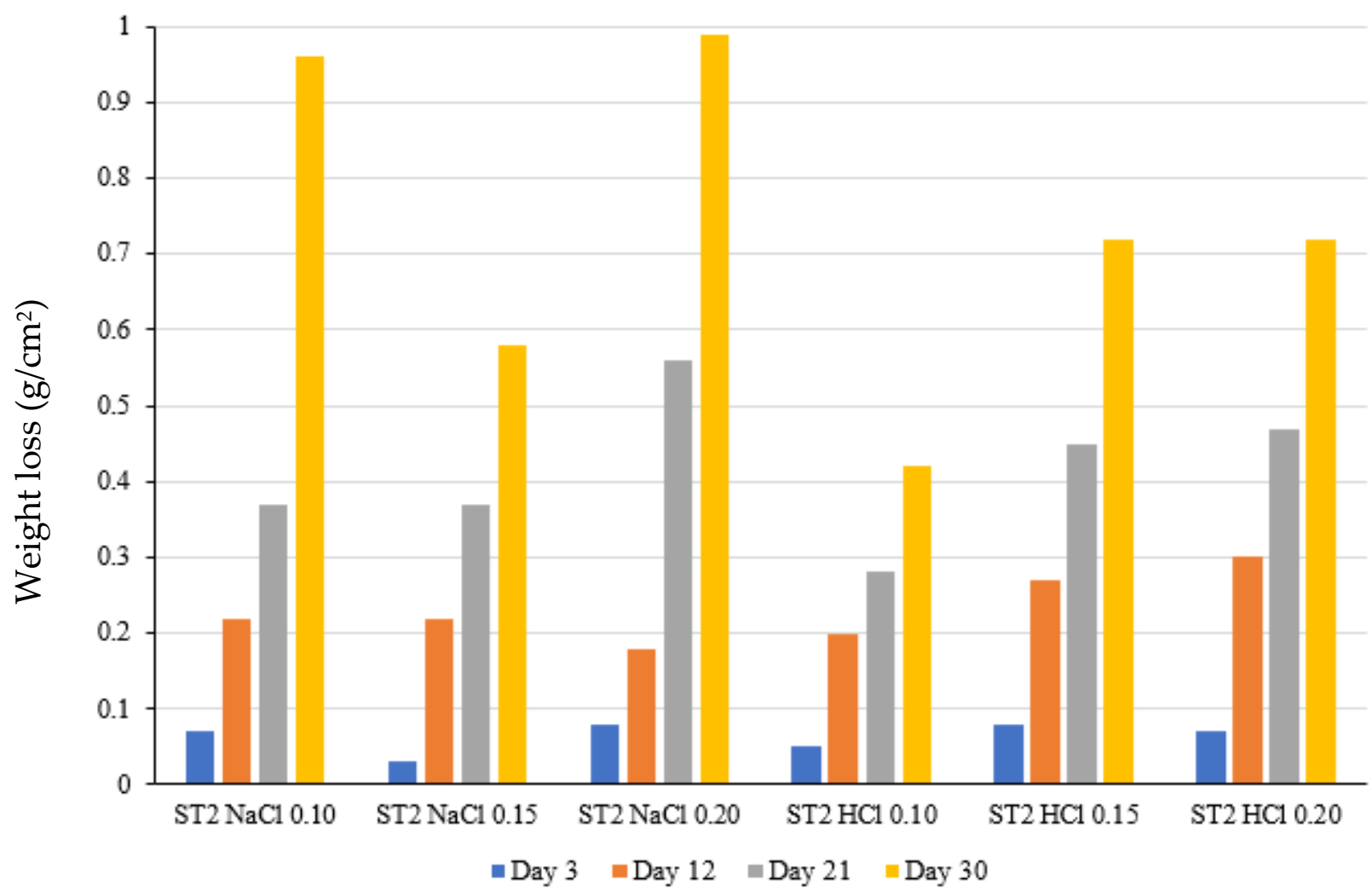

Figure 8. Effect of heat treatment on corrosion behaviour of $\mathrm{S}_{\mathrm{T} 2}(4 \%)$.

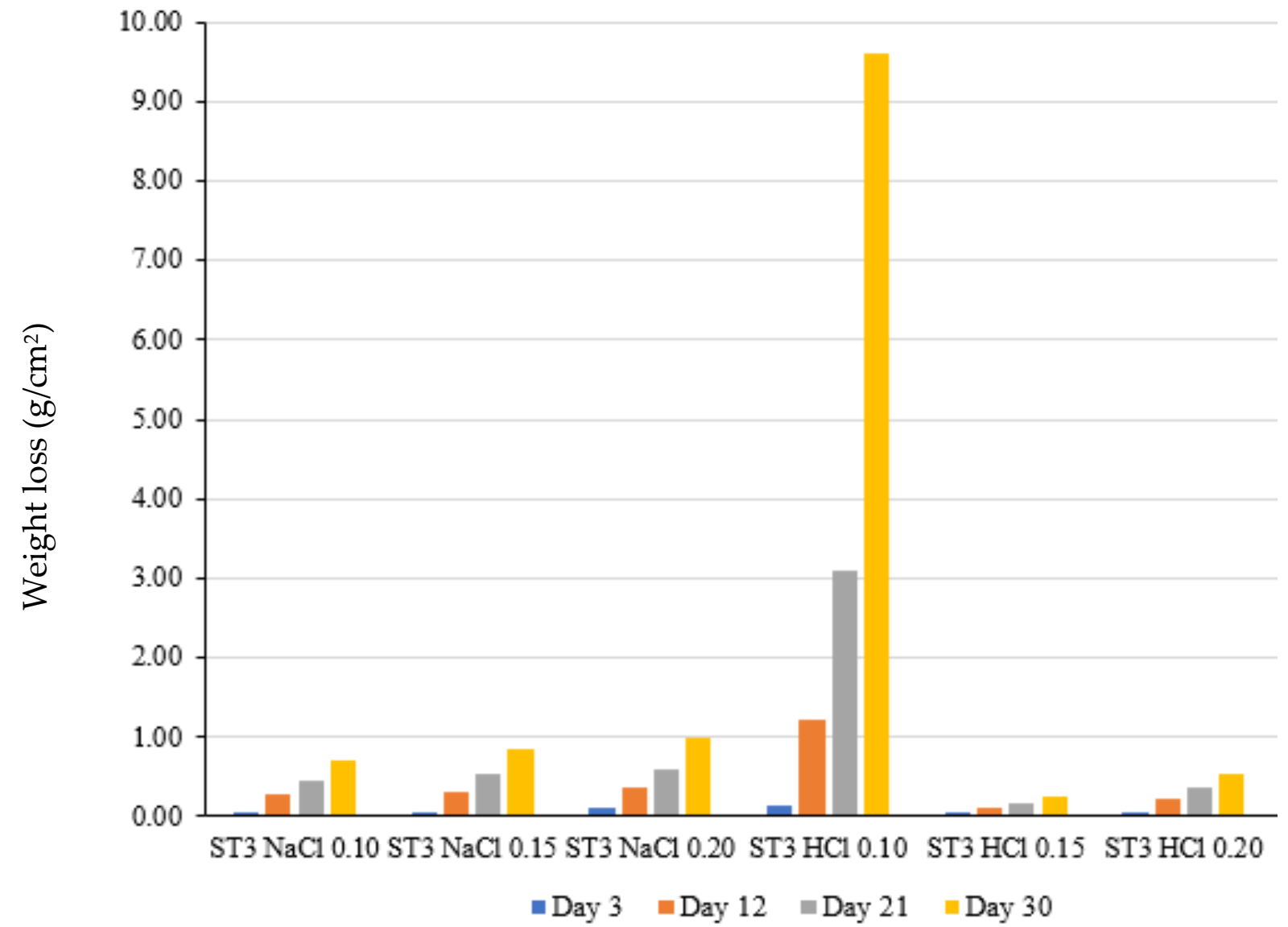

Figure 9. Effect of heat treatment on corrosion behaviour of $\mathrm{S}_{\mathrm{T} 3}(6 \%)$. 
The effect of heat treatment on the corrosion behaviour of AA6063 reinforced with $\mathrm{AgNp}_{3}+\mathrm{CaCO}_{3}$ at $\%\left(\mathrm{~S}_{\mathrm{T} 1}\right), 4 \%\left(\mathrm{~S}_{\mathrm{T} 1}\right)$ and $6 \%\left(\mathrm{~S}_{\mathrm{T} 3}\right)$ were, respectively, shown in Figures 7 and 9. Figure 7 reveals a uniform corrosion rate in all the specimens in $\mathbf{S}_{\mathrm{T} 1}$. It was revealed in Figure 8 that the corrosion rate increased significantly in all the specimens in $S_{\mathrm{T} 2}$ as the reinforced composite increased to $4 \%$, except in $\mathrm{S}_{\mathrm{T} 2} \mathrm{HCl}-0.10$ and $\mathrm{S}_{\mathrm{T} 2} \mathrm{HCl}-0.20$ where the weight loss was reduced by $71 \%$ and $4 \%$, respectively. With addition of $6 \% \mathrm{AgNp}_{3}+\mathrm{CaCO}_{3}$, the weight loss reduced again by $65 \%$ in $\mathrm{S}_{\mathrm{T} 3} \mathrm{HCl}-0.15$ (from $0.72 \mathrm{~g}$ to $0.25 \mathrm{~g}$ ) and $25 \%$ in $\mathrm{S}_{\mathrm{T} 3} \mathrm{HCl}-0.20$ (from $0.72 \mathrm{~g}$ to $0.54 \mathrm{~g}$ ) but increased rapidly in $\mathrm{S}_{\mathrm{T} 3} \mathrm{HCl}-0.10$ from $0.42 \mathrm{~g}$ to $9.61 \mathrm{~g}$ (over $2000 \%$ increase in weight).

Figures 10-12 show the effect of heat treatment on the corrosion behaviour of AA6063 reinforced with $\mathrm{CaCO}_{3}$ at $2 \%\left(\mathrm{~S}_{\mathrm{T} 4}\right), 4 \%\left(\mathrm{~S}_{\mathrm{T} 5}\right)$ and $6 \%\left(\mathrm{~S}_{\mathrm{T} 6}\right)$, respectively, and these data are presented in Table 10. Figure 10 revealed a linear reduction in the weight of all the specimens in $\mathrm{S}_{\mathrm{T} 4}$ with $\mathrm{S}_{\mathrm{T} 4} \mathrm{HCl}-0.10$ and $\mathrm{S}_{\mathrm{T} 4} \mathrm{HCl}-0.20$ more affected than other specimens with over $100 \%$ increase in weight loss on average every 10 days for 30 days in both specimens. It is revealed in Figure 11 that the corrosion rate increased significantly in four out of the six specimens in $\mathrm{S}_{\mathrm{T} 5}$ as the reinforced composite increased to $4 \%$, except in $\mathrm{S}_{\mathrm{T} 5} \mathrm{NaCl}-0.10$ and $\mathrm{S}_{\mathrm{T} 5} \mathrm{HCl}-0210$ where the weight loss was reduced by $35 \%$ and $27 \%$, respectively. With the addition of $6 \% \mathrm{CaCO}_{3}$, a saw-tooth pattern was observed in the corrosion behaviour shown in Figure 12, as weight loss reduced in specimens $\mathrm{S}_{\mathrm{T} 6} \mathrm{NaCl}-0.15$ and $\mathrm{S}_{\mathrm{T} 6} \mathrm{HCl}-0.10$ by $36 \%$ and $54 \%$, respectively, and increased in the remaining four specimens. Johna et al. [46] investigated the weight loss method for corrosion behaviour of AMC and found that the immersion time, the nature of the electrolyte or solution and the percentage of reinforcement contribute significantly to the weight loss and corrosion rate. This was also confirmed in this research. All the parameters optimised, such as concentration and type of corrosion medium, immersion type of the sample, percentage weight of the reinforcement and the heat treatment process affect the corrosion rate substantially.

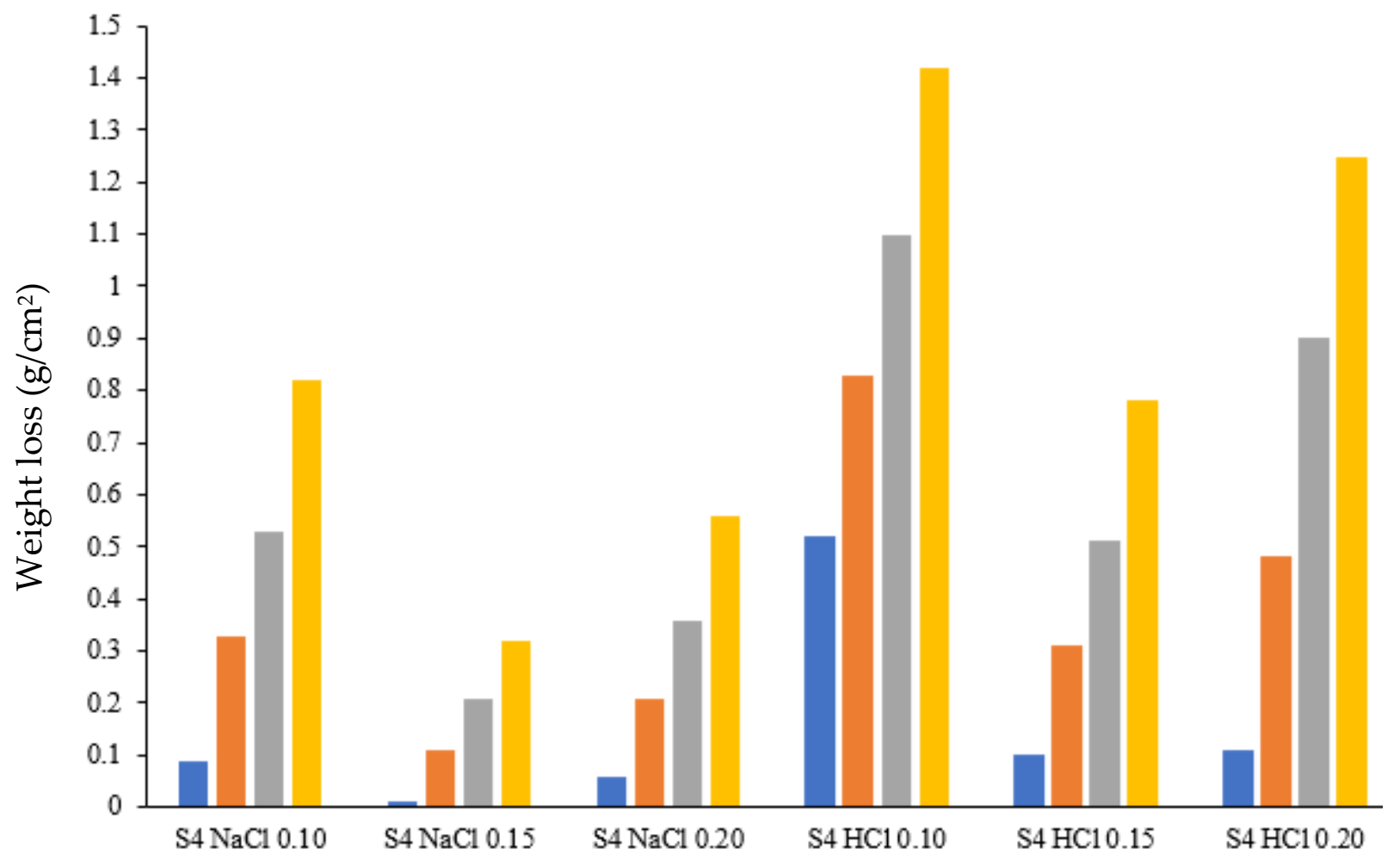

Figure 10. Effect of heat treatment on corrosion behaviour of $\mathrm{S}_{\mathrm{T} 4}(2 \%)$. 


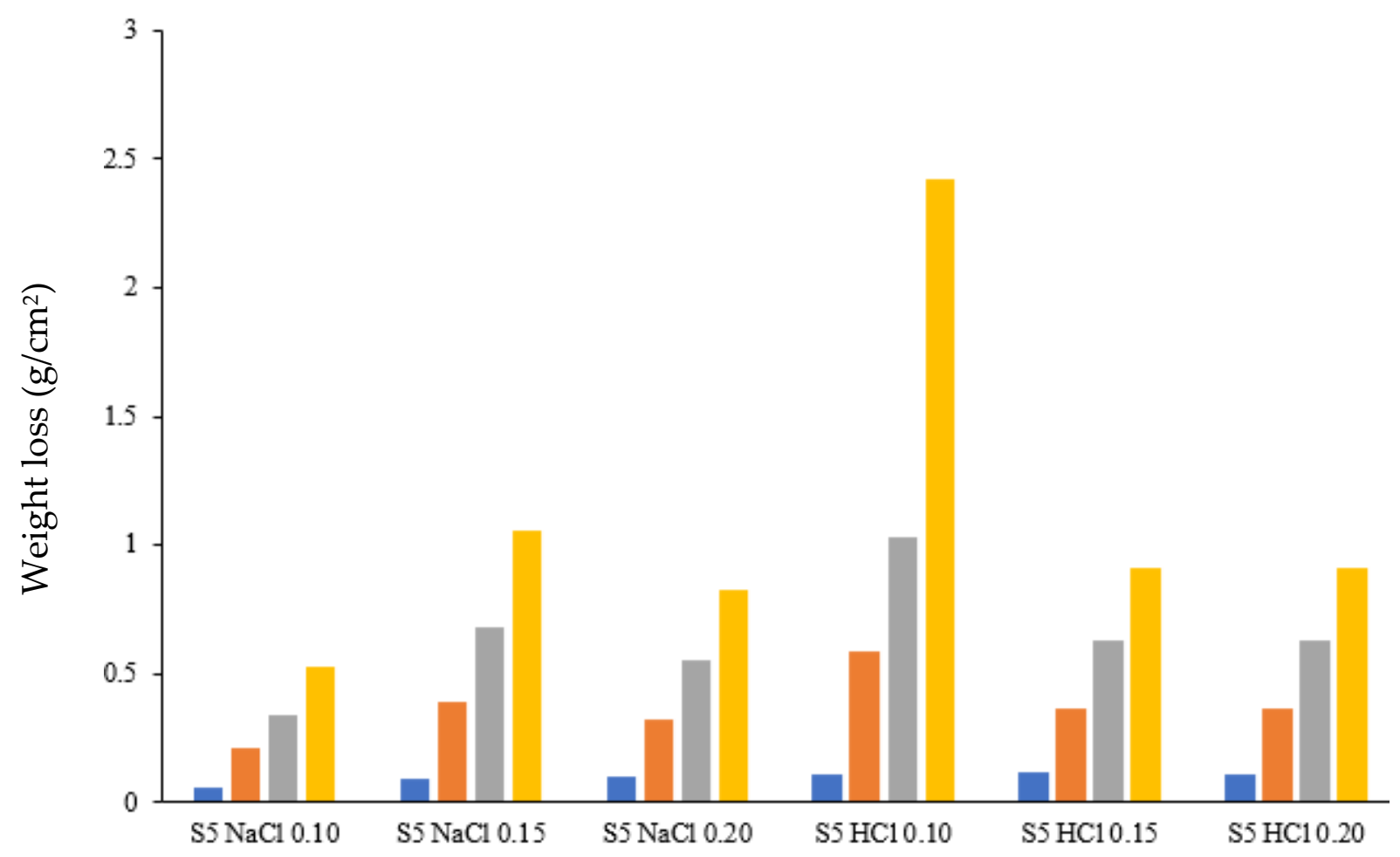

Figure 11. Effect of heat treatment on corrosion behaviour of $\mathrm{S}_{\mathrm{T} 5}(4 \%)$.

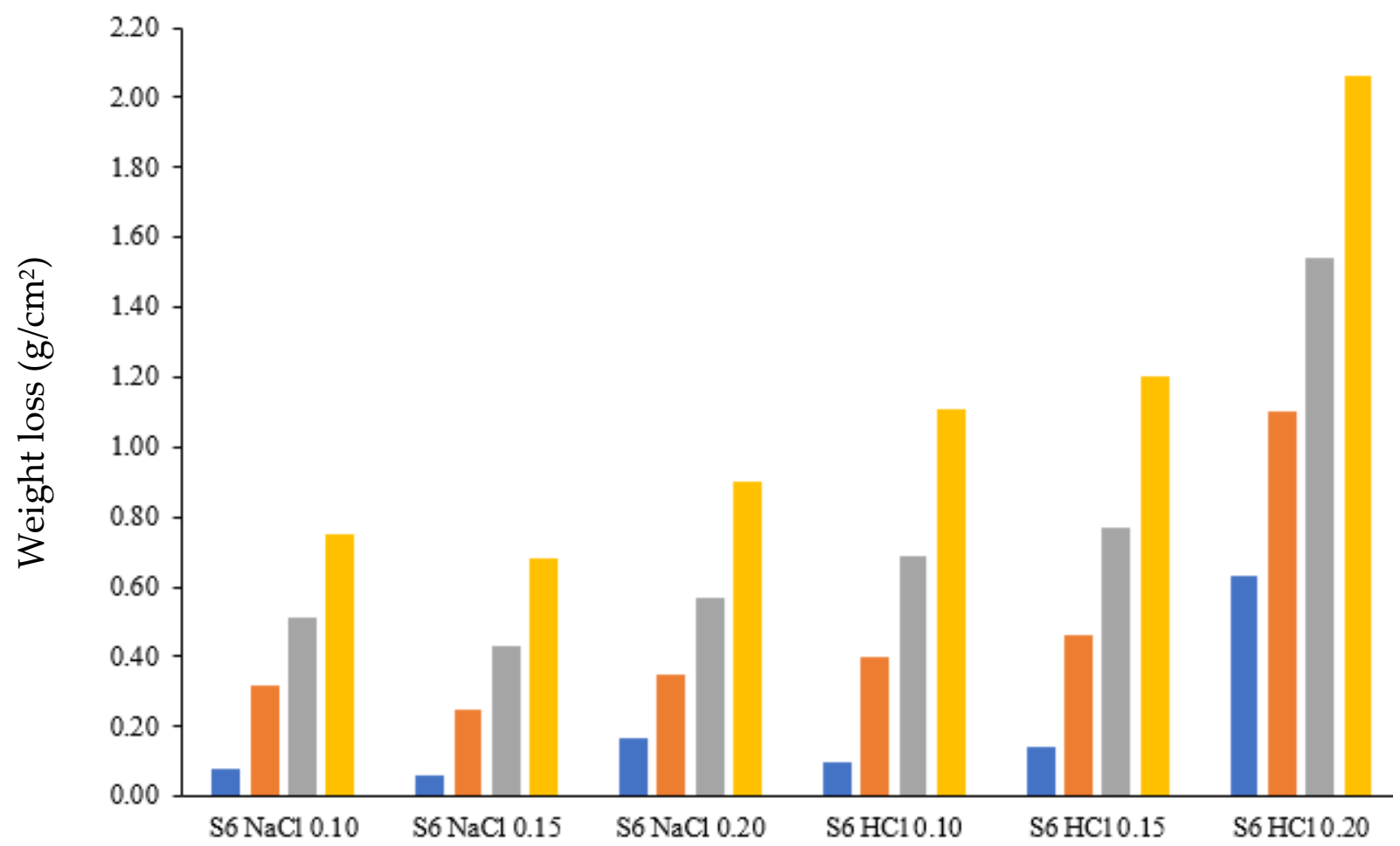

Figure 12. Effect of heat treatment on corrosion behaviour of $\mathrm{S}_{\mathrm{T} 6}(6 \%)$. 
Table 10. Specimen $\mathrm{S}_{\mathrm{T} 4}, \mathrm{~S}_{\mathrm{T} 5}$ and $\mathrm{S}_{\mathrm{T} 6}$ weight reduction in $\mathrm{HCl}$ and $\mathrm{NaCl}$.

\begin{tabular}{|c|c|c|c|c|c|c|}
\hline \multirow{2}{*}{ S.N } & \multirow{2}{*}{ Composite $\left(\mathrm{CaCO}_{3}\right)$} & \multirow{2}{*}{ Specimen Label } & \multicolumn{4}{|c|}{ Specimen Weight Reduction (g) } \\
\hline & & & Day 3 & Day 12 & Day 21 & Day 30 \\
\hline \multirow{6}{*}{10} & \multirow{6}{*}{$\mathrm{S}_{\mathrm{T} 4} 2 \%$} & $\mathrm{~S}_{\mathrm{T} 4} \mathrm{NaCl} 0.10$ & 0.09 & 0.33 & 0.53 & 0.82 \\
\hline & & $\mathrm{S}_{\mathrm{T} 4} \mathrm{NaCl} 0.15$ & 0.01 & 0.11 & 0.21 & 0.32 \\
\hline & & $\mathrm{S}_{\mathrm{T} 4} \mathrm{NaCl} 0.20$ & 0.06 & 0.21 & 0.36 & 0.56 \\
\hline & & $\mathrm{S}_{\mathrm{T} 4} \mathrm{HCl} 0.10$ & 0.52 & 0.83 & 1.10 & 1.42 \\
\hline & & $\mathrm{S}_{\mathrm{T} 4} \mathrm{HCl} 0.15$ & 0.10 & 0.31 & 0.51 & 0.78 \\
\hline & & $\mathrm{S}_{\mathrm{T} 4} \mathrm{HCl} 0.20$ & 0.11 & 0.48 & 0.90 & 1.25 \\
\hline \multirow{6}{*}{11} & \multirow{6}{*}{$\mathrm{S}_{\mathrm{T} 5} 4 \%$} & $\mathrm{~S}_{\mathrm{T} 5} \mathrm{NaCl} 0.10$ & 0.06 & 0.21 & 0.34 & 0.53 \\
\hline & & $\mathrm{S}_{\mathrm{T} 5} \mathrm{NaCl} 0.15$ & 0.09 & 0.39 & 0.68 & 1.06 \\
\hline & & $\mathrm{S}_{\mathrm{T} 5} \mathrm{NaCl} 0.20$ & 0.10 & 0.32 & 0.55 & 0.83 \\
\hline & & $\mathrm{S}_{\mathrm{T} 5} \mathrm{HCl} 0.10$ & 0.11 & 0.59 & 1.03 & 2.42 \\
\hline & & $\mathrm{S}_{\mathrm{T} 5} \mathrm{HCl} 0.15$ & 0.12 & 0.37 & 0.63 & 0.91 \\
\hline & & $\mathrm{S}_{\mathrm{T} 5} \mathrm{HCl} 0.20$ & 0.11 & 0.37 & 0.63 & 0.91 \\
\hline \multirow{6}{*}{12} & \multirow{6}{*}{$\mathrm{S}_{\mathrm{T} 6} 6 \%$} & $\mathrm{~S}_{\mathrm{T} 6} \mathrm{NaCl} 0.10$ & 0.08 & 0.32 & 0.51 & 0.75 \\
\hline & & $\mathrm{S}_{\mathrm{T} 6} \mathrm{NaCl} 0.15$ & 0.06 & 0.25 & 0.43 & 0.68 \\
\hline & & $\mathrm{S}_{\mathrm{T} 6} \mathrm{NaCl} 0.20$ & 0.17 & 0.35 & 0.57 & 0.90 \\
\hline & & $\mathrm{S}_{\mathrm{T} 6} \mathrm{HCl} 0.10$ & 0.10 & 0.40 & 0.69 & 1.11 \\
\hline & & $\mathrm{S}_{\mathrm{T} 6} \mathrm{HCl} 0.15$ & 0.14 & 0.46 & 0.77 & 1.20 \\
\hline & & $\mathrm{S}_{\mathrm{T} 6} \mathrm{HCl} 0.20$ & 0.63 & 1.10 & 1.54 & 2.06 \\
\hline
\end{tabular}

The control specimens were cut out from the as received sample containing $100 \%$ AA6063 without any reinforcement. The result of the corrosion test conducted for 30 days on the heat-treated and unheated specimen's $C$ and $C_{T}$ using the weight reduction method is presented in Table 11. Figure 13 shows the corrosion behaviour of unheated AA6063 specimen (C) without any reinforced composite in $0.10 \mathrm{M}, 0.15 \mathrm{M}$ and $0.20 \mathrm{M}$ of $\mathrm{HCl}$ and $\mathrm{NaCl}$ for 30 days, while Figure 14 illustrates that of heat-treated AA6063 specimen $\left(\mathrm{C}_{\mathrm{T}}\right)$ soaked in the media for the same number of days. Both figures revealed a linear reduction in the weight of both specimens, with specimen $C$ more corroded than specimen $C_{T}$ by $0.28 \mathrm{~g}$.

Table 11. Control specimens $\mathrm{C}$ and $\mathrm{C}_{\mathrm{T}}$ weight reduction in $\mathrm{HCl}$ and $\mathrm{NaCl}$.

\begin{tabular}{|c|c|c|c|c|c|c|}
\hline \multirow{2}{*}{ S.N } & \multirow{2}{*}{ AA6063 (100\%) } & \multirow{2}{*}{ Specimen Label } & \multicolumn{4}{|c|}{ Specimen Weight Reduction (g) } \\
\hline & & & Day 3 & Day 12 & Day 21 & Day 30 \\
\hline \multirow{6}{*}{13} & \multirow{6}{*}{$\mathrm{C}$} & $\mathrm{C} \mathrm{NaCl} 0.10$ & 0.15 & 0.58 & 0.97 & 1.52 \\
\hline & & $\mathrm{C} \mathrm{NaCl} 0.15$ & 0.34 & 0.56 & 0.75 & 1.02 \\
\hline & & $\mathrm{C} \mathrm{NaCl} 0.20$ & 0.09 & 0.31 & 0.52 & 0.94 \\
\hline & & $\mathrm{C} \mathrm{HCl} 0.10$ & 0.12 & 0.56 & 0.94 & 1.43 \\
\hline & & $\mathrm{C} \mathrm{HCl} 0.15$ & 0.05 & 0.17 & 0.27 & 0.35 \\
\hline & & $\mathrm{C} \mathrm{HCl} 0.20$ & 0.06 & 0.19 & 0.31 & 0.45 \\
\hline \multirow{6}{*}{14} & \multirow{6}{*}{$\mathrm{C}_{\mathrm{T}}$} & $\mathrm{C}_{\mathrm{T}} \mathrm{NaCl} 0.10$ & 0.13 & 0.52 & 0.87 & 1.37 \\
\hline & & $\mathrm{C}_{\mathrm{T}} \mathrm{NaCl} 0.15$ & 0.07 & 0.30 & 0.53 & 0.84 \\
\hline & & $\mathrm{C}_{\mathrm{T}} \mathrm{NaCl} 0.20$ & 0.08 & 0.32 & 0.56 & 0.84 \\
\hline & & $\mathrm{C}_{\mathrm{T}} \mathrm{HCl} 0.10$ & 0.11 & 0.53 & 0.92 & 1.45 \\
\hline & & $\mathrm{C}_{\mathrm{T}} \mathrm{HCl} 0.15$ & 0.10 & 0.43 & 0.71 & 1.08 \\
\hline & & $\mathrm{C}_{\mathrm{T}} \mathrm{HCl} 0.20$ & 0.06 & 0.24 & 0.39 & 0.60 \\
\hline
\end{tabular}




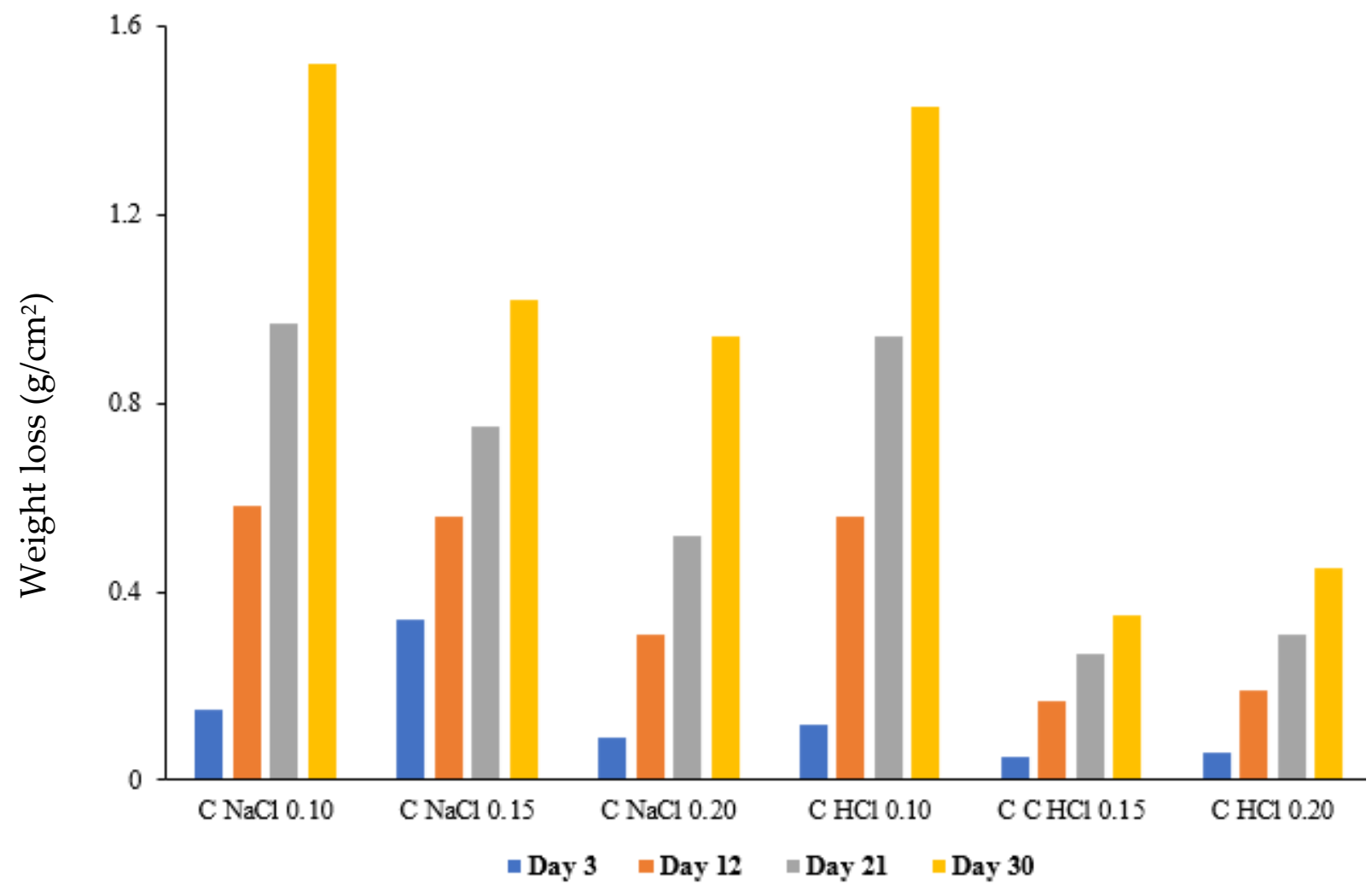

Figure 13. Comparison of the corrosion behaviour of unheated specimen $\mathrm{C}$ in $\mathrm{HCl}$ and $\mathrm{NaCl}$.

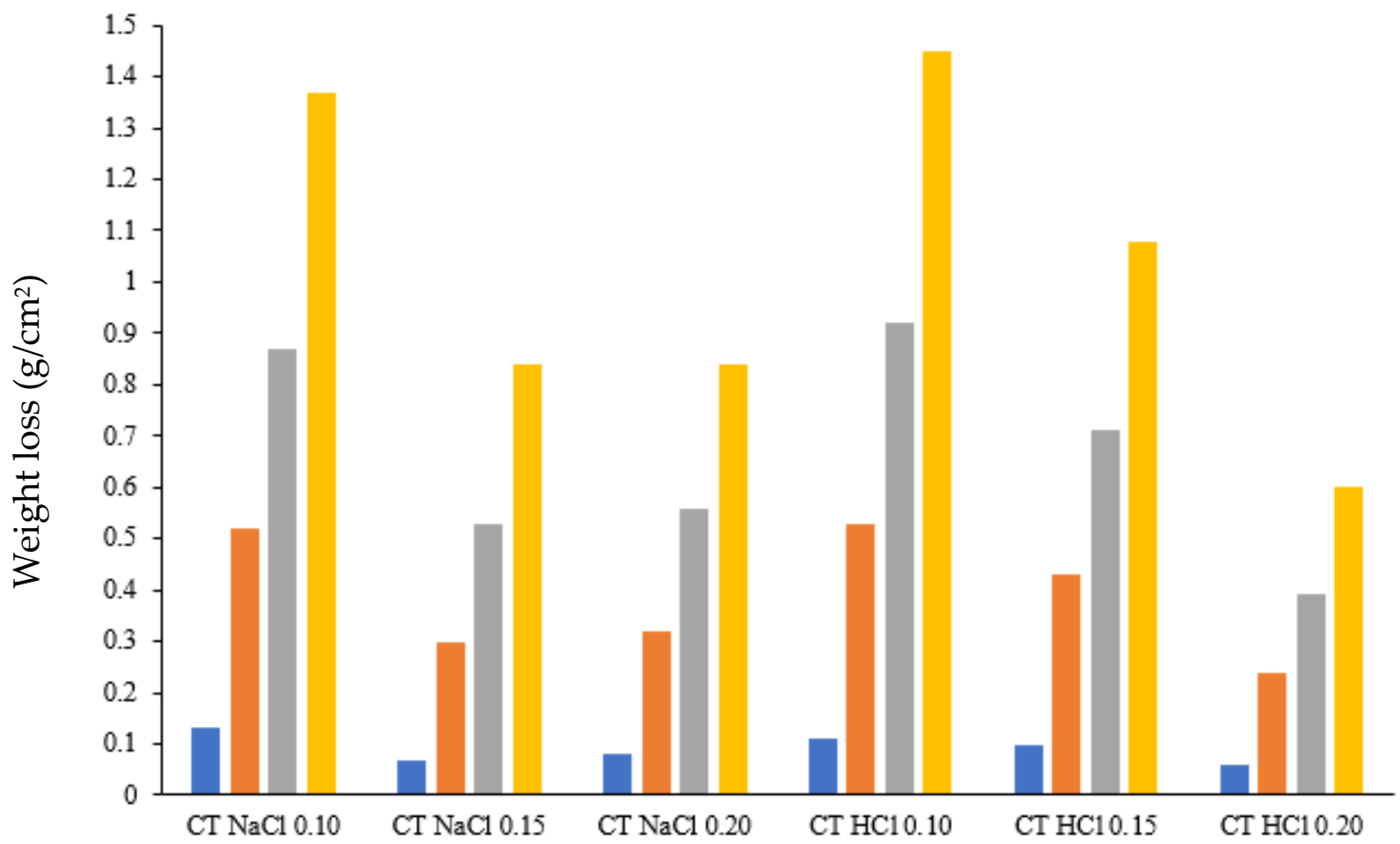

Figure 14. Effect of heat treatment on corrosion behaviour of $C_{T}$.

The heat treatment process results in the recrystallisation of the Aluminium alloys, thereby enhancing the heat-treated aluminium alloys to form a protective oxide layer faster than the untreated samples. The formation of black layers was noticed on the heat-treated samples after day 3 of the corrosion test. This has been reported to be the presence of 
hydrogen-hydroxyl-chloride which results from the diffusion and reaction between the electrolyte and the surface of the material. This black layer acts as a protective barrier and mitigates the further surface diffusion of the electrolytes in the bulk materials [47].

\section{Micrographs of the Corroded Samples}

The macrographs taken at $1 \mathrm{~mm}$ at different corrosion times in different electrolytes $(\mathrm{NaCl}$ and $\mathrm{HCl})$ are presented in Figures 15 and 16, respectively. From Figure 15, the formation of a mixed brownish and whitish layer was noticed after 3 days due to the cathodic and anodic electrochemical activities happening on the surface of the AMC. The whitish layer has been identified to be Aluminium oxide from previous research studies $[31,32,37,39,44]$. The aluminium oxide is a protective and barrier layer that prevents the further diffusion of the $\mathrm{Cl}^{-}$in the electrolyte. It is worth noting that all the samples tend to show almost the same corrosion evolution process. The major difference is the percentage of area covered after oxidation takes place in the corrosive environment, and this ultimately affects weight loss in the AMC depending on the concentration of the electrolytes and reinforcement particles. This informed the decision to add only one macrograph each for $\mathrm{NaCl}$ and $\mathrm{HCl}$ electrolytes. After 12 days, the corrosion propagated, and a substantial area was covered with different corrosive layers. An additional blackish layer was noticed on the surface. The formation of this black layer could be due to starvation of oxygen in the electrolytes, thereby reducing the rate of spontaneous formation of aluminium oxide protective layers in the AMC. The black layer was further explained in the latter part of this research. This phenomenon continued for 21 and 30 days, respectively, with an increase in the surface area covered by the corrosive layers. Almost the same process was also noticed in the $\mathrm{HCl}$ electrolyte, as presented in Figure 16. The formations of the blackish layer can also be attributed to the presence of a high concentration of $\mathrm{Cl}^{-}$in the $\mathrm{NaCl}$ and $\mathrm{HCl}$ electrolytes.
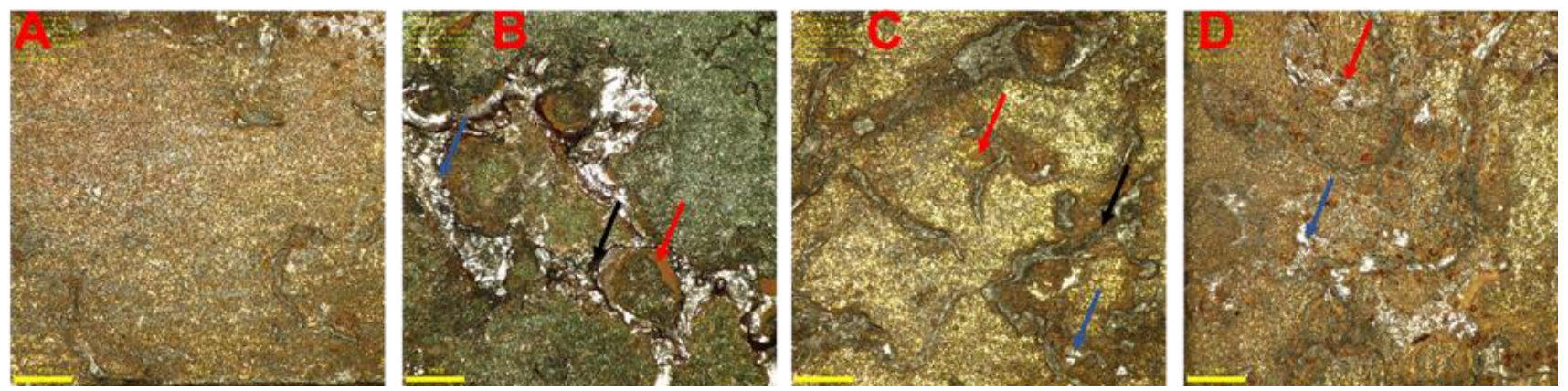

Figure 15. The corroded surface of sample $\mathrm{S} 2\left(4 \% \mathrm{AgNp}+\mathrm{CaCO}_{3}\right)$ in $0.10 \mathrm{NaCl}$. (A) 3 days (B) 12 days (C) 21 days and (D) 30 days.
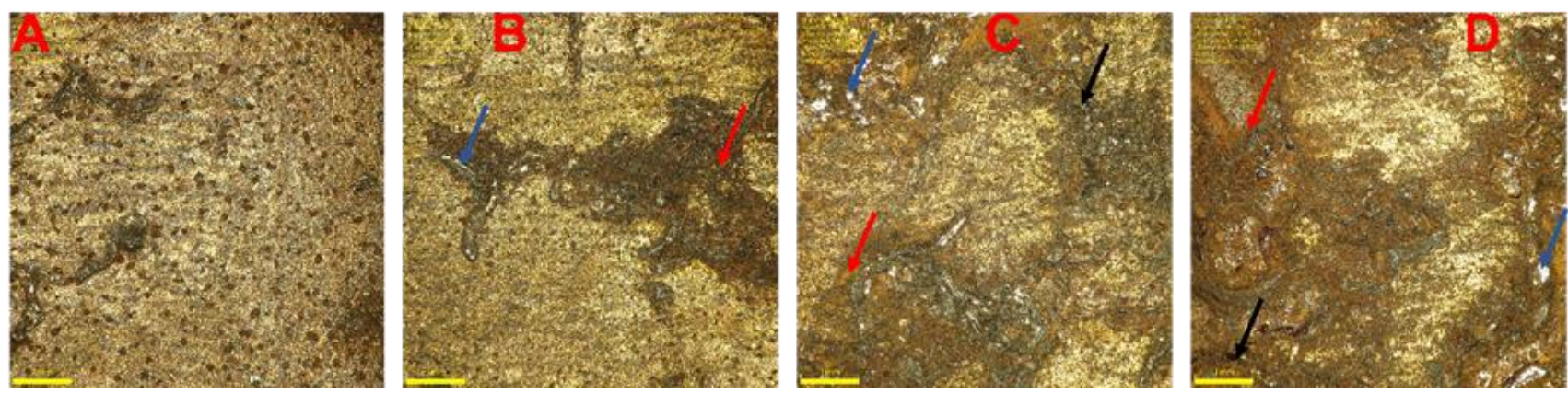

Figure 16. The corroded surface of sample $\mathrm{S} 2\left(4 \% \mathrm{AgNp}+\mathrm{CaCO}_{3}\right)$ in $0.10 \mathrm{HCl}$. (A) 3 days (B) 12 days (C) 21 days and (D) 30 days. 


\section{Conclusions}

The major accomplishment of this research work is establishing the influence of heat treatment on the corrosion behaviour of an aluminium-silver nano particle (AA6063/AgNp) matrix composite soaked into $\mathrm{NaCl}$ and $\mathrm{HCl}$ separately at $0.10 \mathrm{M}, 0.15 \mathrm{M}$ and $0.2 \mathrm{M}$ concentrations. It was established from this study that heat treatment reduces the corrosion rate in the control specimen (AA6063) not impregnated with AgNp when it met $\mathrm{NaCl}$ in three different concentrations $(0.1 \mathrm{M}, 0.15 \mathrm{M}$, and $0.1 \mathrm{M})$ for 30 days.

It was also established that the heat treatment reduced corrosion rate in AA6063 impregnated with the $2 \%$ wt. silver nano particle $\left(\mathrm{AgNp}+\mathrm{CaCO}_{3}\right)$ soaked in $0.1 \mathrm{M}$, $0.15 \mathrm{M}$ and $0.20 \mathrm{M}$ concentrated $\mathrm{NaCl}$ solution for 30 days or in $0.15 \mathrm{M}$ concentration of $\mathrm{HCl}$ solution when the composite weight composition increased to $4 \%$ and $6 \%$. It also reduces weight loss due to corrosion in $\mathrm{AA} 6063 / \mathrm{AgNp}+\mathrm{CaCO}_{3}$ with $4 \%$ wt. composite composition soaked in $0.1 \mathrm{M}$ and $0.15 \mathrm{M}$ concentrated $\mathrm{NaCl}$ solution for 30 days or in $0.1 \mathrm{M}$ concentrated $\mathrm{NaCl}$ solution for $6 \%$ wt. composite composition. Similarly, heat treatment increased the corrosion-resistant properties of the $\mathrm{AA} 6063 / \mathrm{CaCO}_{3}$ matrix alloy with $2 \%$ and $6 \% \mathrm{wt}$ composite composition when soaked in $0.10 \mathrm{M}$ concentration of the $\mathrm{HCl}$ solution. In the same way, its treatment reduced the corrosion rate in AA6063 impregnated with 4\% $\mathrm{CaCO}_{3}$ soaked in $0.10 \mathrm{M}$, and $0.20 \mathrm{M}$ concentrated $\mathrm{NaCl}$ solution or $0.10 \mathrm{M}$, and $0.15 \mathrm{M}$ concentrated $\mathrm{NaCl}$ solution for $6 \%$ wt the composite composition.

Author Contributions: Conceptualization, O.M.I.; methodology, O.M.I., P.K.-E. and H.A.B.; software, H.A.B. and O.O.A.; validation, O.M.I., H.A.B. and O.O.A.; formal analysis, O.M.I.; investigation, P.K.-E.; resources, E.T.A. and S.A.A. (Stephen A. Akinlabi); data curation, S.A.A. (Stephen A. Akinlabi) and S.A.A. (Sunday Adeniran Afolalu); writing-original, H.A.B. and P.K.-E.; preparation, O.M.I.; writing-review and editing, O.M.I.; supervision, O.M.I. and E.T.A.; project administration, S.A.A. (Sunday Adeniran Afolalu); funding acquisition, E.T.A. and S.A.A. (Stephen A. Akinlabi); All authors have read and agreed to the published version of the manuscript.

Funding: This research received no external funding.

Data Availability Statement: The data presented in this study are available on request from the corresponding author.

Conflicts of Interest: The authors declare no conflict of interest.

\section{References}

1. Anand Babu, K.; Venkataramaiah, P.; Dharma Reddy, K. Mechanical characterization of aluminium hybrid metal matrix composites synthesized by using stir casting process. Mater. Today Proc. 2018, 5, 28155-28163. [CrossRef]

2. Venkata Ravi Kumar, S.; Muniappan, A.; Mohanavel, V. Investigation of $\mathrm{SiC}$ and $\mathrm{Al}_{2} \mathrm{O}_{3}$ - Reinforced with aluminium compositesA review. Mater. Today Proc. 2020. [CrossRef]

3. Abegunde, O.O.; Akinlabi, E.T.; Madyira, D. Microstructural Evolution and Mechanical Characterizations of Al-TiC Matrix Composites Produced via Friction Stir Welding. Mater. Tehnol. 2017, 51, 297-306. [CrossRef]

4. Hanizam, H.; Salleh, M.S.; Omar, M.Z.; Sulong, A.B. Optimisation of mechanical stir casting parameters for fabrication of carbon nanotubes-aluminium alloy composite through Taguchi method. J. Mater. Res. Technol. 2019, 8, 2223-2231. [CrossRef]

5. Hashim, J.; Looney, L.; Hashmi, M. Metal matrix composites: Production by the stir casting method. J. Mater. Process. Technol. 1999, 92, 1-7. [CrossRef]

6. Kainer, K.U. Basics of Metal Matrix Composites; Wiley Online Library: Hoboken, NJ, USA, 2006.

7. Kandpal, B.C.; Kumar, J.; Singh, H. Production technologies of metal matrix composite: A review. IJRMET 2014, 4, 27-32.

8. Kandpal, B.C.; Kumar, J.; Singh, H. Manufacturing and technological challenges in stir casting of metal matrix composites-A review. Mater. Today Proc. 2018, 5, 5-10. [CrossRef]

9. Kumar, A.; Singh, R.; Singh, I. A review of metal inert gas welding on aluminium alloys. Int. J. Eng. Sci. Res. Technol. 2017, 6, 453-456.

10. Magnani, G.; Brentari, A.; Burresi, E.; Raiteri, G. Pressureless sintered silicon carbide with enhanced mechanical properties obtained by the two-step sintering method. Ceram. Int. 2014, 40, 1759-1763. [CrossRef]

11. Zhang, J.; Jiang, D.; Lin, Q.; Chen, Z.; Huang, Z. Properties of silicon carbide ceramics from gelcasting and pressureless sintering. Mater. Des. 1980-2015 2015, 65, 12-16. [CrossRef]

12. Zhang, W.; Yamashita, S.; Kita, H. Progress in tribological research of SiC ceramics in unlubricated sliding-A review. Mater. Des. 2020, 190, 108528. [CrossRef] 
13. Zhang, P.; Zhang, W.; Du, Y.; Wang, Y. High-performance Al-1.5 wt $\% \mathrm{Si}_{-} \mathrm{Al}_{2} \mathrm{O}_{3}$ composite by vortex-free high-speed stir casting. J. Manuf. Process. 2020, 56, 1126-1135. [CrossRef]

14. Ribeiro, S.; Gênova, L.; Ribeiro, G.; Oliveira, M.; Bressiani, A. Effect of heating rate on the shrinkage and microstructure of liquid phase sintered SiC ceramics. Ceram. Int. 2016, 42, 17398-17404. [CrossRef]

15. Ortiz, A.; Borrero-López, O.; Quadir, M.Z.; Guiberteau, F. A route for the pressureless liquid-phase sintering of SiC with low additive content for improved sliding-wear resistance. J. Eur. Ceram. Soc. 2012, 32, 965-973. [CrossRef]

16. Kumar, A.; Singh, R.C.; Chaudhary, R. Recent progress in production of metal matrix composites by stir casting process: An overview. Mater. Today Proc. 2020, 21, 1453-1457. [CrossRef]

17. Khodaei, M.; Yaghobizadeh, O.; Shahraki, A.A.; Esmaeeli, S. Investigation of the effect of $\mathrm{Al}_{2} \mathrm{O}_{3}-\mathrm{Y}_{2} \mathrm{O}_{3}-\mathrm{CaO}(\mathrm{AYC})$ additives on sinterability, microstructure and mechanical properties of $\mathrm{SiC}$ matrix composites: A review. Int. J. Refract. Met. Hard Mater. 2019, 78, 9-26. [CrossRef]

18. Gurusamy, P.; Tamilselvan, S.; Saravanan, S.; Nantha Gopal, D. Experimental investigation of AA2014 alloy with reinforcement of fly ash and SiC hybrid composites by stir casting method. Mater. Today Proc. 2020, 33, 3342-3346. [CrossRef]

19. Nirala, A.; Soren, S.; Kumar, N.; Kaushal, D.R. A comprehensive review on mechanical properties of Al-B ${ }_{4}$ C stir casting fabricated composite. Mater. Today Proc. 2020, 21, 1432-1435. [CrossRef]

20. Ramanathan, A.; Krishnan, P.K.; Muraliraja, R. A review on the production of metal matrix composites through stir castingFurnace design, properties, challenges, and research opportunities. J. Manuf. Process. 2019, 42, 213-245. [CrossRef]

21. Rana, R.; Purohit, R.; Das, S. Reviews on the influences of alloying elements on the microstructure and mechanical properties of aluminum alloys and aluminum alloy composites. Int. J. Sci. Res. Publ. 2012, 2, 1-7.

22. Fan, Z.; Niu, H.; Cantor, B.; Miodownik, A.; Saito, T. Effect of $\mathrm{Cl}$ on microstructure and mechanical properties of in situ Ti/TiB MMCs produced by a blended elemental powder metallurgy method. J. Microsc. 1997, 185, 157-167. [CrossRef]

23. Sharma, D.K.; Mahant, D.; Upadhyay, G. Manufacturing of metal matrix composites: A state of review. Mater. Today Proc. 2020, 26, 506-519. [CrossRef]

24. Imran, M.; Khan, A.R.A. Characterization of Al-7075 metal matrix composites: A review. J. Mater. Res. Technol. 2019, 8, 3347-3356. [CrossRef]

25. Bunshah, R.F. Deposition Technologies for Films and Coatings: Developments and Applications; William Andrew: Norwich, NY, USA, 1994; ISBN 978081551746.

26. Kumar, U.K.A.V. Method of stir casting of aluminum metal matrix composites: A review. Mater. Today Proc. 2017, 4, 1140-1146. [CrossRef]

27. Pakdel, A.; Witecka, A.; Rydzek, G.; Shri, D.N.A.; Nicolosi, V. A comprehensive analysis of extrusion behavior, microstructural evolution, and mechanical properties of $6063 \mathrm{Al}-\mathrm{B}_{4} \mathrm{C}$ composites produced by semisolid stir casting. Mater. Sci. Eng. A 2018, 721, 28-37. [CrossRef]

28. Raja, R.; Jannet, S.; Reji, S.; Glen Paul, C.S. Analysis of mechanical and wear properties of $\mathrm{Al}_{2} \mathrm{O}_{3}+\mathrm{SiC}+\mathrm{B} 4 \mathrm{C} / \mathrm{AA} 5083$ hybrid metal matrix composite done by stir casting route. Mater. Today Proc. 2020, 26, 1626-1630. [CrossRef]

29. Srivastava, A.K. Assessment of mechanical properties and EDM machinability on Al6063/SiC MMC produced by stir casting. Mater. Today Proc. 2020, 25, 630-634. [CrossRef]

30. Udoye, N.E.; Nnamba, O.J.; Fayomi, O.S.I.; Inegbenebor, A.O.; Jolayemi, K.J. Analysis on mechanical properties of AA6061/Rice husk ash composites produced through stir casting technique. Mater. Today Proc. 2020, 43, 1415-1420. [CrossRef]

31. Christy, J.V.; Arunachalam, R.; Mourad, A.I.; Krishnan, P.K.; Piya, S.; Al-Maharbi, M. Processing, Properties, and Microstructure of Recycled Aluminum Alloy Composites Produced through an Optimized Stir and Squeeze Casting Processes. J. Manuf. Process. 2020, 59, 287-301. [CrossRef]

32. Khalili, V.; Heidarzadeh, A.; Moslemi, S.; Fathyunes, L. Production of Al6061 matrix composites with $\mathrm{ZrO}_{2}$ ceramic reinforcement using a low-cost stir casting technique: Microstructure, mechanical properties, and electrochemical behavior. J. Mater. Res. Technol. 2020, 9, 15072-15086. [CrossRef]

33. Kumar, D.D.; Kumar, N.; Kalaiselvam, S.; Dash, S.; Jayavel, R. Wear resistant super-hard multilayer transition metal-nitride coatings. Surf. Interfaces 2017, 7, 74-82. [CrossRef]

34. Kumar Maurya, N.; Maurya, M.; Srivastava, A.K.; Dwivedi, S.P.; Kumar, A.; Chauhan, S. Investigation of mechanical properties of Al6061/SiC composite prepared through stir casting technique. Mater. Today Proc. 2020, 25, 755-758. [CrossRef]

35. Arun Kumar, S.; Hari Vignesh, J.; Paul Joshua, S. Investigating the effect of porosity on aluminium 7075 alloy reinforced with silicon nitride $\left(\mathrm{Si}_{3} \mathrm{~N}_{4}\right)$ metal matrix composites through STIR casting process. Mater. Today Proc. 2020, 39, 414-419. [CrossRef]

36. Madhukar, P.; Selvaraj, N.; Gujjala, R.; Rao, C.S.P. Production of high performance AA7150-1\% SiC nanocomposite by novel fabrication process of ultrasonication assisted stir casting. Ultrason. Sonochem. 2019, 58, 104665. [CrossRef]

37. Nageswaran, G.; Natarajan, S.; Ramkumar, K.R. Synthesis, structural characterization, mechanical and wear behaviour of $\mathrm{Cu}-\mathrm{TiO}_{2}-\mathrm{Gr}$ hybrid composite through stir casting technique. J. Alloy. Compd. 2018, 768, 733-741. [CrossRef]

38. Raj, S.S.; Kannan, T.K.; Kathiresan, M.; Balachandar, K.; Krishnakumar, S. Why not stir casting for polymer composites? Investigations on poly lactic acid based wood plastic composite. Mater. Today Proc. 2020, 45, 862-868. [CrossRef]

39. Sachinkumar, S.; Narendranath, S.; Chakradhar, D. Studies on microstructure and mechanical characteristics of as cast AA6061/SiC/fly ash hybrid AMCs produced by stir casting. Mater. Today Proc. 2020, 20, A1-A5. [CrossRef] 
40. Yadav, R.; Gupta, R.K.; Goyal, A. Study of tribological behaviour of hybrid metal matrix composites prepared by stir casting method. Mater. Today Proc. 2020, 28, 2218-2222. [CrossRef]

41. Carreño-Gallardo, C.; Mendoza-Duarte, J.; Lopez-Melendez, C.; Estrada-Guel, I.; Martinez-Sanchez, R. Evaluation of mechanical properties of aluminum alloy (Al-2024) reinforced with carbon-coated silver nanoparticles (AgCNP) metal matrix composites. Microsc. Microanal. 2015, 21, 1041-1042. [CrossRef]

42. Estrada-Ruiz, R.; Flores-Campos, R.; Herrera-Ramírez, J.; Martinez-Sanchez, R. Mechanical properties of aluminum 7075-Silver nanoparticles powder composite and its relationship with the powder particle size. Adv. Powder Technol. 2016, 27, 1694-1699. [CrossRef]

43. Sosimi, A.; Gbenebor, O.; Oyerinde, O.; Bakare, O.; Adeosun, S.; Olaleye, S.A. Analysing wear behaviour of $\mathrm{Al}_{-} \mathrm{CaCO}_{3}$ composites using ANN and Sugeno-type fuzzy inference systems. Neural Comput. Appl. 2020, 32, 13453-13464. [CrossRef]

44. Adeodu, A.; Mudashiru, L.; Daniyan, I.; Awodoyin, A. Effect of silver nanoparticle (AgNp) mixed with calcium carbonate on impact, hardness and tensile strength properties of aluminium 6063. J. Compos. Mater. 2020, 0021998320923141. [CrossRef]

45. Loto, R.T.; Adeleke, A. Corrosion of aluminum alloy metal matrix composites in neutral chloride solutions. J. Fail. Anal. Prev. 2016, 16, 874-885. [CrossRef]

46. Johna, C.F.; Paulb, R.C.; Singhc, S.C.E.; Jacobjosed, J.; Ramkumare, T.; Sengottuvelf, P. Weight Loss Method for corrosion behaviour of Al-12si-ZrC Composites Using Response Surface Methodology. Int. J. Appl. Eng. Res. 2018, 13, 4428-4433.

47. Chandra, B.T.; Shivashankar, H. Effect of heat treatment on hardness of Al7075-Albite particulate composites. Mater. Today Proc. 2017, 4, 10786-10791. [CrossRef] 